\title{
Tephra without Borders: Far-Reaching Clues into Past Explosive Eruptions
}

\author{
Vera Ponomareva ${ }^{1 *}$, Maxim Portnyagin ${ }^{2,3}$ and Siwan M. Davies ${ }^{4}$ \\ ${ }^{1}$ Institute of Volcanology and Seismology, Petropavlovsk-Kamchatsky, Russia, ${ }^{2}$ GEOMAR Helmholtz Centre for Ocean \\ Research Kiel, Kiel, Germany, ${ }^{3}$ Vernadsky Institute of Geochemistry and Analytical Chemistry, Moscow, Russia, ${ }^{4}$ Department \\ of Geography, College of Science, Swansea University, Swansea, UK
}

This review is intended to highlight recent exciting advances in the study of distal (>100 km from the source) tephra and cryptotephra deposits and their potential application for volcanology. Geochemical correlations of tephra between proximal and distal locations have extended the geographical distribution of tephra over tens of millions square kilometers. Such correlations embark on the potential to reappraise volume and magnitude estimates of known eruptions. Cryptotephra investigations in marine, lake, and ice-core records also give rise to continuous chronicles of large explosive eruptions many of which were hitherto unknown. Tephra preservation within distal ice sheets

OPEN ACCESS

Edited by:

Antonio Costa,

Istituto Nazionale di Geofisica e

Vulcanologia, Italy

Reviewed by:

Victoria C. Smith,

University of Oxford, UK

Roberto Sulpizio,

Università degli Studi di Bari, Italy

David M. Pyle,

University of Oxford, UK

*Correspondence:

Vera Ponomareva

vera.ponomareva1@gmail.com

Specialty section:

This article was submitted to Volcanology,

a section of the journal

Frontiers in Earth Science

Received: 14 July 2015 Accepted: 30 November 2015 Published: 22 December 2015

Citation:

Ponomareva V, Portnyagin M and Davies SM (2015) Tephra without Borders: Far-Reaching Clues into Past

Explosive Eruptions.

Front. Earth Sci. 3:83.

doi: 10.3389/feart.2015.00083 and varved lake sediments permit precise dating of parent eruptions and provide new insight into the frequency of eruptions. Recent advances in analytical methods permit an examination of magmatic processes and the evolution of the whole volcanic belts at distances of hundreds and thousands of kilometers from source. Distal tephrochronology has much to offer volcanology and has the potential to significantly contribute to our understanding of sizes, recurrence intervals and geochemical make-up of the large explosive eruptions.

Keywords: tephra, tephrochronology, cryptotephra, explosive eruptions, volcanic glass

\section{INTRODUCTION}

Modern humankind has limited experience of living through a large explosive volcanic eruption. Of the $~ 30$ largest explosive eruptions known to have occurred in the last 2000 years (Brown et al., 2014) only a few were described by witnesses (e.g., AD 1883 Krakatau or AD 1815 Tambora) and only one (1991 Pinatubo) was monitored with the help of ground-based, air- and satellite-borne instruments. The others were reconstructed based on tephra deposits left by the eruptions. Pinatubo was not the largest in this list as its tephra production was an order of magnitude less than that of Tambora (Wiesner et al., 2004; Kandlbauer and Sparks, 2014). Although the impacts of the Tambora eruption have been reconstructed based on contemporary evidence and climate proxies (e.g., Oppenheimer, 2003; Stoffel et al., 2015), we still do not have sufficient knowledge of how similar event could affect the modern world.

The infamous Eyjafjallajökull eruption ash cloud that disrupted air travel over Europe and North Atlantic in April-May 2010 caused an economic loss of $€ 5$ billion (Oxford Economics, 2010). The total magma volume for this eruption was estimated at $\sim 0.18 \mathrm{~km}^{3}$ (Gudmundsson et al., 2012). In contrast, Pinatubo magma volume was roughly estimated at $4.8-6 \mathrm{~km}^{3}$ (Wiesner et al., 2004) and that of Tambora-at $\sim 41 \mathrm{~km}^{3}$ (Kandlbauer and Sparks, 2014), and so based on magma volume these eruptions were one and two orders of magnitude larger than Eyjafjallajökull, respectively. 
In the intricately interconnected modern world, both immediate and long-term effects of similar future events on various human activities are hard to predict.

One of the prerequisites of predicting future giant eruptions is the understanding of sizes and recurrence times of past similar events (Self and Gertisser, 2015). The existing global catalog of the large explosive eruptions, however, is far from complete (e.g., Brown et al., 2014). Even for the last millennium, new findings are frequently added to the growing list of eruptions and it is thought that only $40 \%$ of explosive eruptions are reported between AD 1500 and 1900 (Deligne et al., 2010; Brown et al., 2014). One of the most recent additions includes the previously unknown caldera-forming eruption of Samalas volcano in $\mathrm{AD} 1257$ (Lavigne et al., 2013). Furthermore, the source of the AD 1809 eruption, which preceded Tambora and left a sulfate signal both in Greenland and Antarctic ice (Dai et al., 1991), is still unknown. What is more, the size of documented explosive eruptions is often poorly constrained and the majority of estimates are based solely on proximal deposits. Despite ongoing efforts aimed to improve our knowledge of past eruptions we still do not know how many large explosive eruptions happened on Earth, even in the Quaternary period. As Self and Gertisser (2015) conclude in their paper dedicated to the Tambora bicentennial: "It is high time for a systematic exploration of all available eruption archives... so that we have a better chance to understand potential future hazards" (pp. 249-250).

A continuous effort is, however, underway to add more eruptions to the existing catalogs and to significantly contribute to their size estimates. For the Quaternary time, this effort is largely undertaken by geographers and archeologists in their pursuit of distal tephra and cryptotephra deposits in areas that are remote to the active volcanoes. A widespread tephra isochron holds considerable promise for the correlation and dating of disparate depositional successions. Several recent papers provide a review of the significance of tephra for paleoenvironmental and archeological studies (e.g., Lowe, 2011; Riede and Thastrup, 2013; Lane et al., 2014; Lowe and Alloway, 2014; Davies, 2015), and the quickly developing field of cryptotephra studies has been considered a revolution in correlation and precision dating of Quaternary deposits (Davies, 2015). In this review we briefly summarize the most recent advances in distal tephra and cryptotephra research that embark on challenges but also offer new opportunities for volcanologists and petrologists. Distal tephra investigations have been successfully executed on tephras as old as the Proterozoic (e.g., Saylor et al., 2005), however we focus mostly on Quaternary tephras.

\section{NEW ADVANCES IN TEPHRA RESEARCH}

Tephra is fragmental material produced by a volcanic eruption regardless of composition, fragment size or emplacement mechanism (Thorarinsson, 1950). During the eruption, an eruptive cloud is transported and dispersed by the wind, and tephra particles settle mantling the landscape. In this way tephra forms an isochron that directly links various sedimentary successions and permits synchronization of disparate paleoenvironmental archives (e.g., Lowe et al., 2012; Albert et al., 2015). An eruptive cloud has the most far-reaching impact affecting distal areas both with solid and aerosol particles. Near the source, tephra forms a visible deposit but in distal areas the volcanic grains can be deposited in low concentrations and become mixed within the sediments or other host material. These distal shards do not form clear layers that are visible to the naked eye and are referred to as cryptotephra (Lowe and Hunt, 2001).

Extensive geochemical fingerprinting of single volcanic glass shards buried in marine, lake, cave and peat deposits as well as in the ice has led to the discovery of cryptotephra deposits in regions where tephra research has never been attempted. Several tephra and cryptotephra deposits have recently been identified at distances of $5000-7000 \mathrm{~km}$ from their source volcanoes (e.g., Coulter et al., 2012; Narcisi et al., 2012; Pyne-O’Donnell et al., 2012; Lane et al., 2013b; Jensen et al., 2014). Such fartraveled ash clouds may not initially seem surprising, given the long-distance transport of dust particles (e.g., Garrison et al., 2003; Delmonte et al., 2010). Volcanic ash, found far from the source, however, is different from dust. First, it signals a strong explosive eruption; second, many tephras can be connected to their source volcanoes or volcanic zones via their unique geochemical fingerprint (e.g., Kutterolf et al., 2008a; Gudmundsdóttir et al., 2011; Lane et al., 2011; Smith et al., 2011b, 2013; Tomlinson et al., 2015). With recent advances in microanalytical techniques, the composition of micronsized individual ash particles can be characterized. Electron microprobe and laser ablation-inductively coupled plasma-mass spectrometry (LA-ICP-MS) permit the determination of major, minor and trace-element abundances and lead $(\mathrm{Pb})$ isotope data (Tomlinson et al., 2010; Kuehn et al., 2011; Hayward, 2012; Pearce et al., 2014; Kimura et al., 2015; Maruyama et al., in press). These techniques allow characterization of glass, minerals, and melt inclusions in minerals to support correlations between widely dispersed locations as well as to the source areas (e.g., Lowe, 2011; Matsu'ura et al., 2011; Smith et al., 2011c). Such long-distance correlations present new opportunities for reconstructing past eruptive history, eruptions size estimates as well as geochemical specifics of the erupted products.

\section{RECORD OF EXPLOSIVE ERUPTIONS: IDENTIFICATION AND DATING OF THE LARGE EXPLOSIVE EVENTS}

Near vent deposits from the largest explosive eruptions usually form packages that are tens to hundreds of meters thick. In regions of highly explosive volcanism these packages from different volcanoes may overlap forming pyroclastic successions. However, stratigraphic relationships of individual units in such successions may be very complex and the deposits can be partly or completely eroded especially in glaciated or coastal areas (e.g., Rawson et al., 2015). Proximal deposits of near-coast volcanoes are also spread and hidden under water. As a result, near-vent deposits of large explosive eruptions in many cases cannot be put into detailed and reliable stratigraphic context. Tephra deposited 
and preserved in distal environments, however, often provide a well-resolved stratigraphic sequence and considerable insight into the frequency of large eruptions that are sometimes not recognized in proximal sequences.

Large $(M>7)$ and well-studied Quaternary eruptions originate from eruptive centers such as Toba, Taupo, Changbaishan (Tianchi), Campi Flegrei, Mazama, Tambora, and Santorini, yet many more large eruptions remain undiscovered. Indeed, according to analysis of the Smithsonian Volcanoes of the World database (Siebert et al., 2010) only about 30\% of the world's volcanoes have eruptive records before $1500 \mathrm{AD}$ (Loughlin et al., 2015). North Pacific volcanic arcs, especially Kurile-Kamchatka and Alaska-Aleutians, definitely hosted many large eruptions, the magnitudes of which are not known. The Alaska-Aleutian volcanic arc hosts at least 14 calderas $>5 \mathrm{~km}$ in diameter, with some being nested (Figure 1; www.avo.alaska.edu). Tephra volumes for some of these eruptions have been roughly estimated at $10-50 \mathrm{~km}^{3}$ based on proximal deposits (Miller and Smith, 1987). Prevailing westerly winds, however, indicate a common transport pathway from the Alaska-Aleutian arc over Alaska where distal tephras provide evidence of these large eruptions. For example, studies of Old Crow tephra ( $124 \mathrm{ka})$ allowed Preece et al. (2011) to identify a Tambora-size or even larger eruption and tentatively associate it with the Emmons Lake volcanic center. In fact, the Klondike goldfields in northwestern Canada lying $\sim 330 \mathrm{~km}$ downwind from the closest volcano can be considered a tephra bonanza. Fifty late Cenozoic tephra layers in this area have been cataloged, each likely to represent large but previously undocumented explosive eruptions from the Wrangell volcanic field and eastern Aleutian arc (Westgate et al., 2011). Further mapping of these tephras and identification of their source volcanoes will significantly contribute to a global catalog of large explosive eruptions.

A further example of the potential of distal work lies within the sediments of the El'gygytgyn Lake (Far East Russian Arctic). Eight visible tephra layers $(0.5-7 \mathrm{~cm}$ thick) have been identified, seven of which have been ascribed to Kurile-Kamchatka, and one-possibly to the Alaska-Aleutian arc (van den Bogaard et al., 2014). This lake lies $>1100 \mathrm{~km}$ from the closest islandarc volcano and in a location that is perpendicular or against the direction of the jet stream. Thus, these layers may represent eruptions that rank within the Earth's largest Quaternary events. However, only one tephra from the El'gygytgyn core was tentatively correlated to the source, which permitted identification of a previously unknown $M>6.5$ eruption from the Karymsky eruptive center in Kamchatka (Ponomareva et al., 2013a). Specific sources of other tephras are still unknown (van den Bogaard et al., 2014). Kamchatka has the highest concentration of Quaternary calderas per unit of arc length in the world (Figure 1; Hughes and Mahood, 2008). What is more, many calderas are nested and their rims overlap so the real number of caldera-forming eruptions is not known. While Holocene explosive eruptions in Kamchatka are quite well studied (e.g., Braitseva et al., 1995, 1997; Ponomareva et al., 2004, 2013b, 2015), the earlier volcanic history of the region remains incomplete. Welded tuffs surrounding caldera chains are difficult to access and even more difficult to put into stratigraphic context so only few of those have been dated (Braitseva et al., 1995; Bindeman et al., 2010). Marine cores surrounding Kamchatka offer considerable promise to reconstruct the history of volcanic events in this region. For example, three Ocean Drilling Program cores taken in 1993 in NW Pacific $\sim 700 \mathrm{~km}$ downwind from Kamchatka, each contain 41-74 visible Pleistocene tephra layers with several displaying thicknesses of $>1 \mathrm{~m}$ (Cao et al., 1995). Further mapping of these tephras over the northwest Pacific is likely to reveal a suite of previously unrecognized $M>6$ explosive eruptions.

Further afield, eruptive histories are being revisited from distal tephra studies in marine, lake and peat deposits as well as in the ice caps (e.g., Shane and Hoverd, 2002; Wulf et al., 2004, 2008, 2012; Kutterolf et al., 2008a; Kuehn and Negrini, 2010; Sulpizio et al., 2010a,b; Dunbar and Kurbatov, 2011; Abbott and Davies, 2012; Narcisi et al., 2012; Pyne-O'Donnell et al., 2012; Jensen et al., 2013; Smith et al., 2013; Davies et al., 2014; van den Bogaard et al., 2014; Bourne et al., 2015a,b; Lane et al., 2015). By now, distal tephra and cryptotephra research has been successfully undertaken in many regions including Greenland (e.g., Abbott et al., 2012; Abbott and Davies, 2012; Coulter et al., 2012; Bourne et al., 2015b); North Atlantic (e.g., Lacasse and Garbe-Schönberg, 2001; Brendryen et al., 2011; Gudmundsdóttir et al., 2012; Blockley et al., 2014; Davies et al., 2014; Griggs et al., 2014; Voelker and Haflidason, 2015); European mainland (e.g., Caron et al., 2010; Sulpizio et al., 2010a,b; Lane et al., 2011, 2015; Lawson et al., 2012); Mediterranean (Siani et al., 2004; Wulf et al., 2004, 2008, 2012; Paterne et al., 2008; Zanchetta et al., 2011; Albert et al., 2012, 2015; Bourne et al., 2015a; Çağatay et al., 2015; Wutke et al., 2015); in and around Japan (e.g., Park et al., 2003; Matsu'ura et al., 2011; Okuno et al., 2011; Smith et al., 2011b, 2013; Lim et al., 2013); New Zealand (Shane, 2000; Alloway et al., 2005; Shane et al., 2006; Allan et al., 2008; Holt et al., 2011; Shane and Wright, 2011; Lowe et al., 2013); off Central America shore (e.g., Clift et al., 2005; Kutterolf et al., 2008a,b). Many tephras found within these domains have been linked to their source volcanoes based on geochemical correlations with proximal deposits (e.g., Alloway et al., 2005; Gudmundsdóttir et al., 2011; Tomlinson et al., 2012, 2015; Lane et al., 2013a; Smith et al., 2013). Several other regions, however, have considerable promise for the identification of distal tephra deposits and require further laboratory-intensive and meticulous investigations.

Once a tephra record is established, a range of dating techniques can be employed to constrain the timing of explosive eruptions. The best archives for providing precise dates are high-resolution incremental records such as ice-core records and varved marine and lake sediments. Tephra ages can be assigned according to the incremental age and sometimes even the eruptive season can be determined (e.g., Lane et al., 2013a, 2015). The challenge, however, is to find and geochemically fingerprint tiny glass shards from these deposits, and then to correlate them to known eruptions and other occurrences of the same tephra. Despite these challenges, such work is being systematically and successfully executed for the Greenland and Antarctic ice sheets. In Greenland, shards from large eruptions such as the Millenium Changbaishan, Bona-Churchill White 

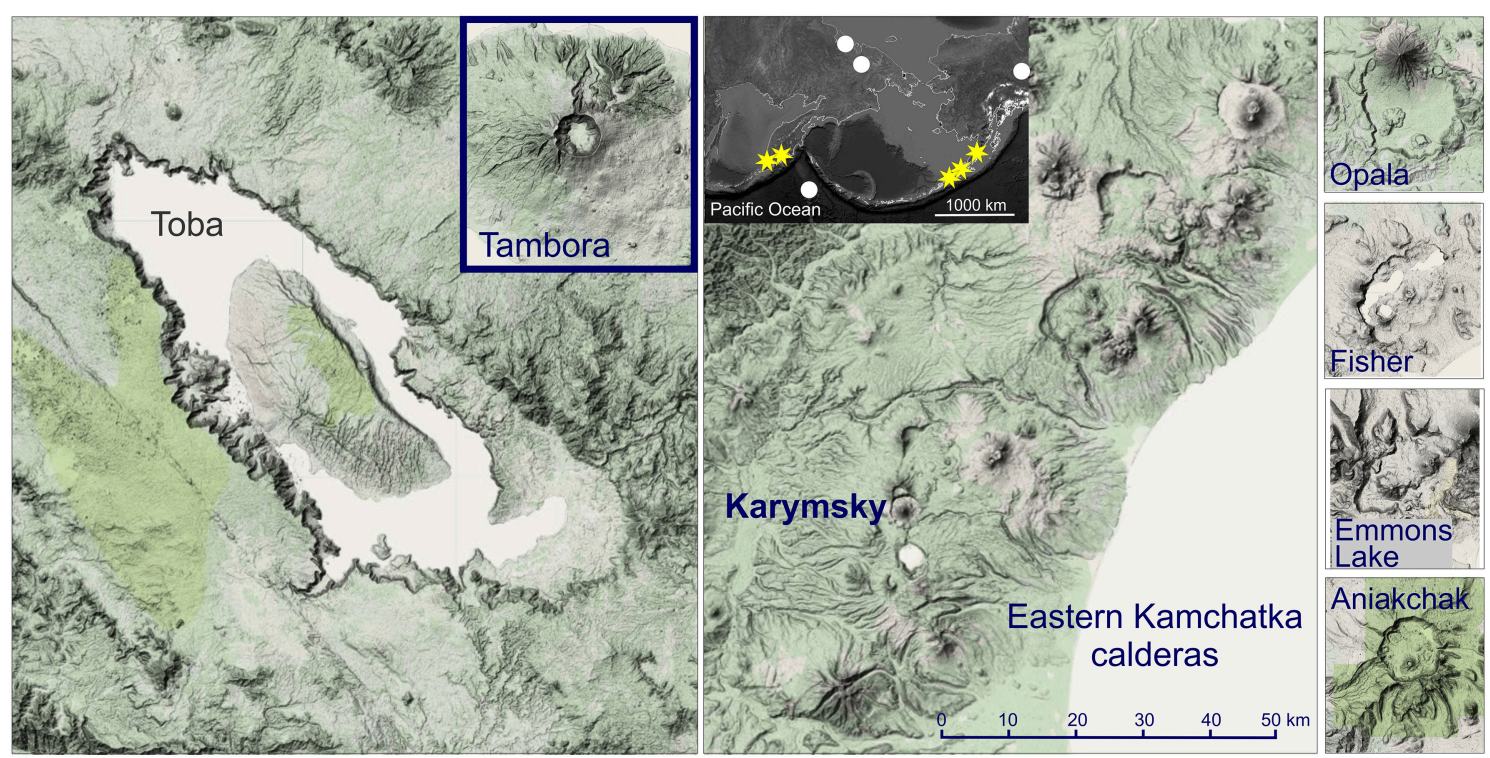

FIGURE 1 | Selected calderas of the North Pacific volcanic arcs in comparison with Toba and Tambora. The Kuril-Kamchatka and Alaska-Aleutian volcanic arcs host more than forty large (5-20 km) Quaternary calderas, many of those are nested. Tephra volumes for most of them were estimated based only on proximal deposits. Only a few tephras related to these caldera-forming eruptions have been mapped (e.g., Kurile Lake, Ponomareva et al., 2004; Old Crow, Preece et al., 2011), and only one (Aniakchak) has been identified as cryptotephra beyond the North Pacific region (Coulter et al., 2012; Pyne-O'Donnell et al., 2012). In the eastern Kamchatka, closely spaced calderas are surrounded by a complex multi-unit ignimbrite sheet. Inset shows locations of the North Pacific calderas presented in the Figure and the sites mentioned in the text. Calderas (yellow stars; from west to east): Opala, Karymsky, Fisher, Emmons Lake, Aniakchak. Sites (white circles; clockwise starting from the low left): Ocean Drilling Program cores 882-884; Rauchua; El'gygytgyn Lake; Klondike gold fields. The images are based on Google Maps with the ASTER GDEM hillshade overlay (ASTER GDEM is a product of METI and NASA). All the maps are brought to one scale.

River ash, Aniakchak, Mazama, and many Icelandic tephras have been identified, which permits age assignations (Abbott and Davies, 2012; Coulter et al., 2012; Sun et al., 2014). Precision of ice dating for some intervals is biannual but even for less resolved parts of the ice cores it is still far better than for any other method. In Antarctic, numerous tephra layers have been identified in icecore records, dated and geochemically linked to both Antarctic and South American volcanoes (Narcisi et al., 2010, 2012; Dunbar and Kurbatov, 2011).

In the absence of bioturbation, rapidly deposited tephra shards form distinct layers or sharp concentration peaks within varved sequences, so downcore counting of seasonal laminations permits direct dating of tephra with annual and sometimes even seasonal resolution (Zolitschka et al., 2015). For example, in varved sediments of Lago Grande di Monticchio, which lies $>100 \mathrm{~km}$ downwind of the Italian volcanoes, more than 350 tephras spanning the last $135 \mathrm{ka}$ have been identified and dated based on ${ }^{14} \mathrm{C}$ dating and age-depth model thus providing a continuous record of explosive volcanism in the area (Wulf et al., 2004, 2008, 2012). In a Late Glacial-Holocene varved record of Meerfelder Maar in the Eifel region of Germany two visible and 15 cryptotephras from Eifel, Icelandic, and Mediterranean sources have been identified and dated (Lane et al., 2013a, 2015). In Japan, a $150 \mathrm{ka}$ long varve record from Lake Suigetsu preserves $\sim 30$ visible tephra layers that have been dated and assigned to explosive eruptions in Japan and South Korea based on their geochemical affinities (Smith et al., 2013).
In non-laminated sequences such as marine, lake and peat deposits tephra ages are usually estimated based on core-specific age-depth models, which are in turn based on astronomic tuning, comparison to oxygen isotope stack, radiocarbon dating or other radiometric techniques etc. (e.g., Lane et al., 2013b). Alternatively, if correlation of certain tephra layers to their dated proximal counterparts is possible, then those proximal dates can be used as fix-points in an age-depth model (e.g., Smith et al., 2011b). Age estimates of the same tephra deposit found in a number of different records (e.g., marine, ice and terrestrial records) also allow a thorough comparison and refinement of ages. For instance, Bronk Ramsey et al. (2015a) and Lowe et al. (2013) adopted a Bayesian approach to refine the ages of 22 European and 24 New Zealand large explosive eruptions.

Provided age determinations can be achieved, tephras preserved within long marine records provide an interesting insight into the temporal patterns of explosive volcanism, which are crucial to inform predictions of future volcanic activity. Eruptive frequency derived from tephra deposits is thought to be highly episodic regionally and even globally, which has allowed identification and dating of regional and global pulses in explosive activity over timescales of hundreds of thousands years (e.g., Paterne et al., 1990; Cambray and Cadet, 1994, 1996; Prueher and Rea, 2001). Temporal clustering within the sequence of Holocene large explosive eruptions has been also demonstrated and statistically verified for the Kamchatka arc (Gusev et al., 2003). Causal mechanisms for this episodicity, especially on a global scale, are still unclear (e.g., Sigurdsson, 
2000). Using time series analysis of tephra layers in circum-Pacific marine cores Kutterolf et al. (2013b) found obliquity-forced variability in late Pleistocene records of volcanic eruptions likely resulting from crustal stress changes associated with ice age mass redistribution. Even if visual description and count of the visible tephra layers in the cores may suffer some inconsistency (over-recording of $\sim 19 \%$ and under-recording of $\sim 10 \%$ of tephra layers) these data can be used as a valid source for data compilations (Mahony et al., 2014). Further studies that improve our volcanic catalogs of the largest explosive eruptions will definitely offer considerable promise for understanding the volcanic pulses and their causes.

\section{ERUPTION SIZES AND TEPHRA DISPERSAL}

The sizes of explosive eruptions are typically expressed as volumes of bulk tephra and/or magma, Volcanic Explosivity Index (VEI) (Newhall and Self, 1982), or magnitude (M) (Pyle, 1995, 2000). All these estimates require knowledge of tephra volume. The latter includes volumes of air-borne tephra deposits (plinian and coignimbrite) and ignimbrite. For caldera-forming eruptions the volume of caldera fill is also included (e.g., Johnston et al., 2014). The proportion of these ingredients may vary between eruptions however volume of air-borne tephra definitely constitutes a very significant part of the total tephra volume. Estimates of this part are normally based on field measurements of tephra thickness and grain-size, which are then used in sophisticated calculations and models (e.g., Bonadonna and Costa, 2012; Costa et al., 2012, 2014; Johnston et al., 2012; Daggitt et al., 2014). Tephra volumes are also used for calculating the amount of climate-affecting volatiles released into the atmosphere (e.g., Metzner et al., 2014). For many large eruptions, however, only proximal $(<100 \mathrm{~km}$ from the source) field data are available, especially for the island arcs, which is not always sufficient for adequate volume calculations.

Distal thickness data dramatically increase the area of tephra dispersal and tephra volumes estimates based on proximal deposits (e.g., Carey et al., 2010). However, recent distal and ultra-distal $(>1000 \mathrm{~km}$ from the source) data are still rarely used in volume calculations. Tephra volume estimates for some well-studied eruptions like Toba have been increasing steadily where more distal tephra occurrences have been added to the dataset and more sophisticated dispersal models were applied (Costa et al., 2012, 2014). Cryptotephra discoveries, however, are difficult to include due to the lack of tephra layer thickness data and low shard concentrations (Costa et al., 2014). Future work may need to consider how glass shard size and concentrations could be integrated into volume estimate models. Recent intercontinental correlations such as the findings of the White River ash (Bona-Churchill volcano in eastern Alaska) in eastern Canada, Greenland and northern Europe (Figure 2; Coulter et al., 2012; Pyne-O'Donnell et al., 2012; Jensen et al., 2014) will hopefully inspire new modeling efforts and lead to improved assessments of the eruptive volumes.
Even if an ultra-distal cryptotephra does not form a continuous veil but is rather deposited in patches because of atmospheric turbulence, rainflush, or some other processes, its deposition area is still far larger than that considered in previous volume calculations. The White River ash has been found along a distinct dispersal pathway from Alaska to Newfoundland, Nova Scotia, Greenland, Ireland, Scotland, Norway, and Germany (Figure 2; Jensen et al., 2014). We hope that other recent findings of pre-historical distal and ultra-distal tephras, for example, Aniakchak (Alaska) ash in eastern Canada and Greenland (Pearce et al., 2004; Coulter et al., 2012; Pyne-O’Donnell et al., 2012), Mazama ash (Cascades) - in many sites in Northern America and in Greenland (Zdanowicz et al., 1999), will soon lead to recalculation of these and other eruptions volumes. If justified, upgrading these eruptions to very large events with their very well-constrained Greenland ice ages will allow us to improve our knowledge of the number and size of eruptions that have occurred in the past.

An understanding of likely dispersal pathways is particularly important for hazard assessment and mitigation (e.g., Shane and Hoverd, 2002). Sulpizio et al. (2014) showed that reconstructed ash-dispersal maps from a number of eruptions can be processed in order to produce frequency maps of distal ash deposition which permits assessment of ash fall hazards over a wide area. Distal tephra records offer considerable insight into this work. In some instances, however, reconstructed dispersal pathways based on tephra occurrences show unexpected patterns. While many plinian eruptive clouds follow jet stream patterns, i.e., are dispersed eastwards, distal and ultra-distal correlations of tephra layers reveal different trajectories for quite a few large tephra plumes. For example, some high-latitude tephra plumes from Kamchatka and Aleutians were dispersed in northerly directions (Figure 2). Among others, Holocene tephra from M7 Kurile Lake caldera $(\mathrm{KO})$ eruption was dispersed to NNW; late Pleistocene Old Crow tephra (supposedly from the Emmons Lake caldera) went to the northeast; and a middle Pleistocene $M>6.5$ Rauchua tephra-to the north (Ponomareva et al., 2004, 2013a; Preece et al., 2011). These examples may indicate different transport pathways that are independent of expected dispersal by the jetstream (e.g., as in Costa et al., 2014, or in Sulpizio et al., 2008, 2013).

\section{TEPHRA AS A MATERIAL FOR PETROLOGICAL AND GEOCHEMICAL STUDIES}

Tephra material often dominates the erupted products in terms of volume, eruption frequency, and variety of compositions some of which may never occur in lava. It is especially true for highly explosive volcanic arcs where the overwhelming majority of the magma is erupted as tephra (e.g., Kutterolf et al., 2008b). But even in the areas traditionally regarded as lava domains, tephra surprisingly dominates in terms of eruption frequency. For example, in Iceland $2 / 3$ of all eruptions in the last 1100 years have been explosive, leaving tephra as their only product (Óladóttir et al., 2012). Similiarly on Kîlauea volcano (Hawaii), 


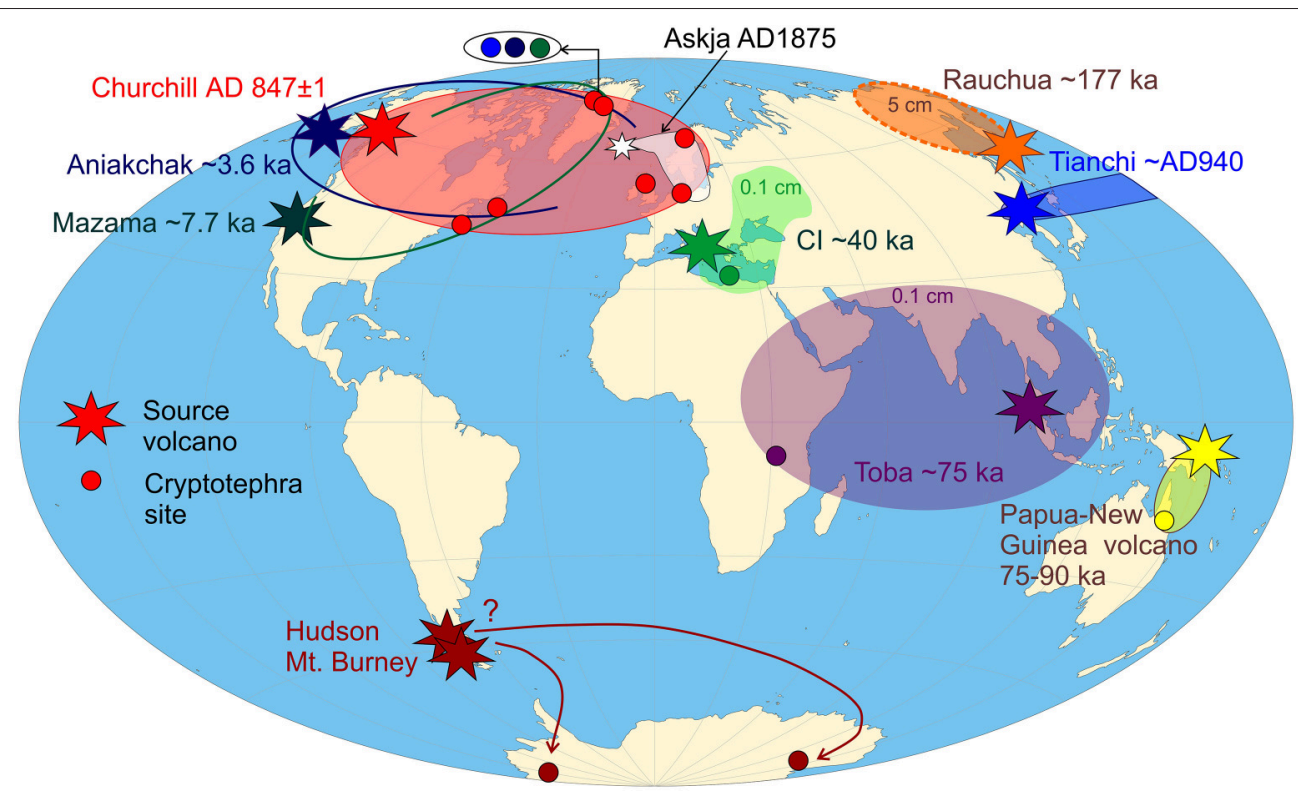

FIGURE 2 | Sketch map illustrating selected intercontinental and ultra-distal correlations of tephra discussed in the text. Tephra dispersal footprints are based on recent cryptotephra findings, and on modeling based on measured thickness of visible tephra layers. An equal area projection ensures visual comparison of the dispersal areas. Probable extent of ash plumes based on cryptotephra findings: Churchill (White River ash), Aniakchak, Mazama, a tephra from Papua-New Guinea (Zdanowicz et al., 1999; Coulter et al., 2009, 2012; Jensen et al., 2014). Ash plumes based on modeling results: Toba and Campanian Ignimbrite (Cl); outer rim at $0.1 \mathrm{~cm}$ (Costa et al., 2012, 2014). Filled circles show selected cryptotephra sites. Tianchi tephra has been found in Greenland ice along with Aniakchak, Churchill and Mazama ones (color circles in and above Greenland; Sun et al., 2014), however, ultra-distal pathway for the Tianchi plume is not constrained. Suggested correlations of some cryptotephras found in the Antarctic ice cores to South American volcanoes (probably Mt. Burney and Hudson) based on Kurbatov et al. (2006) and Narcisi et al. (2012). Well mapped Askja 1875 plume is provided for comparison (Carey et al., 2010). The Rauchua tephra (Kamchatka) 5-cm outline (Ponomareva et al., 2013a). The Rauchua tephra as well as many others mapped only as visible layers in fact may extend well beyond known outlines.

explosive eruptions was the prevailing style for $60 \%$ of eruptions in the last 2500 years (Swanson et al., 2014).

In spite of dominance of tephra in many eruptions, its distal samples were rarely used in petrological research because of the following concerns. Distal tephra samples may be contaminated with xenogenic material, and potential sorting of crystals and glass in the eruption cloud can make the composition of a bulk tephra sample unrepresentative for erupted magma composition (e.g., Braitseva et al., 1997). Additional factor limiting interest of petrologists is that many distal tephras have unknown volcanic source. If the source is known, more rich proximal material is usually available and therefore chosen for detailed petrologic studies. Despite these factors limiting the use of distal tephra in research beyond tephrochronology, some remarkable examples of using distal tephra to study conditions of magma generation are known (e.g., Bryant et al., 2003; Straub et al., 2004, 2010, 2015). They show that the major potential for petrological and geochemical studies of distal tephra is reconstruction of longtime regional variations of composition of explosive volcanism and its correlation with macro-tectonic events. Based on these relatively rare examples, we believe that the value of distal tephra for geochemical studies is still underscored and should be reappraised.

Besides the fact that for most eruptions no other material is available for study but tephra, the petrologists' interest in tephra is triggered by two important features: robust stratigraphic control of tephra deposits and rapid cooling (quenching) upon the eruption. Stratigraphically controlled and often well-dated continuous tephra sequences provide an excellent opportunity for a time-series geochemical study, i.e., analysis of how erupted magma compositions change through time. Rapid cooling of small tephra particles ensures quenching of the melt to glass, which preserves information of the melt composition prior to eruption. The compositional changes provide insight into the variations in magma sources (e.g., Smith et al., 2005), conditions of magma fractionation, and evolution of magmatic flux through time (e.g., Rawson et al., 2015). Such studies are pertinent on time scales ranging from months to millions of years and from individual volcanoes to volcanic arcs or other tectonic arrangements of volcanoes.

Geochemical time-series studies on timescales of months to thousands of years typically address eruptive histories and magmatic evolution of individual volcanoes and mostly focus on proximal terrestrial tephra sequences (e.g., Smith et al., 2005, 2011a; Donoghue et al., 2007; Óladóttir et al., 2008, 2011a,b; Hasegawa et al., 2011; Turner et al., 2011; Firth et al., 2014; Iverson et al., 2014; Schindlbeck et al., 2014; Fontijn et al., 2015; Ponomareva et al., 2015). On a longer time scale (thousands to millions of years), tephras are more readily preserved in nonerosive marine environments that are relatively close to active volcanoes. These depositional settings preserve a continuous 
record of large eruptions from one or few volcanic systems (e.g., Allan et al., 2008; Albert et al., 2012; Gudmundsdóttir et al., 2012; Lim et al., 2013; Bourne et al., 2015b), or from a large volcanic region such as a few hundred $\mathrm{km}$ long volcanic arc (e.g., Arculus et al., 1995; Cao et al., 1995; Clift et al., 2003, 2005; Straub, 2003; Straub and Layne, 2003a,b; Straub et al., 2004, 2010, 2015; Kutterolf et al., 2008a, 2013a). In some cases such long records are also preserved in deposits of existing or paleo-lakes (e.g., Wulf et al., 2004, 2008, 2012; Kuehn and Negrini, 2010; Smith et al., 2013).

For intra-oceanic island-arc systems, marine tephra records provide a unique insight into the history of the arcs as their old magmatic complexes are typically buried under younger volcanics or rifted away during back-arc basin formation. For instance, near-continuous tephra records of large-scale explosive volcanism of the Izu-Bonin island arc for the last $42 \mathrm{Myr}$ (Straub, 2003), the Mariana island-arc for the last $34 \mathrm{Myr}$ (Straub et al., 2015), and the Kermadec arc for the last $\sim 50 \mathrm{ka}$ (Shane and Wright, 2011) were obtained by studying sediments from deep-see drilling holes. These studies provided a new and unprecedented data-set on the temporal evolution of these arc systems. New insights were derived into the composition and evolution of the mantle and slab sources involved in magma genesis and revealed possible correlations between the compositions of erupted magmas and tectonic evolution of the arcs. DSDP/ODP/IODP sediment cores have been obtained offshore many active volcanic arcs such as Kamchatka, Central America, Aleutians, Ecuador, Peru, New Zealand, Japan-IzuBonin-Mariana and all of those contain numerous tephra layers (Cao et al., 1995; Alloway et al., 2005; Hart and Miller, 2006); http://www-odp.tamu.edu). Geochemical fingerprinting of these tephras has been undertaken largely for reconstructions of eruptive frequency and for stratigraphic correlations between the cores. In-depth geochemical research on tephra from most of the cores is still ongoing.

Rapid cooling upon eruption, which results in effective quenching of melt in magma to glass and preservation of pre-eruptive mineral equilibria, makes tephra a very attractive product for petrologic studies. These studies are usually aimed at quantification of physicochemical conditions of magma evolution at depth and during ascent to the surface. Several studies have focused on elucidating the volatile content in magmas prior to eruption by analysis of glassy melt inclusions in phenocrysts (e.g., Wallace, 2005; Blundy and Cashman, 2008) and on magma degassing by comparison of the compositions of matrix glasses and melt inclusions (e.g., Devine et al., 1984; Thordarson et al., 1996; Wallace, 2001; Kutterolf et al., 2015). Textural analysis of tephra particles has also been successfully used to reconstruct shallow crystallization and degassing processes occurring in magmatic systems and to correlate them to eruption dynamics (e.g., Hammer et al., 1999; Blundy and Cashman, 2008). Thermobarometric petrologic studies are commonly performed on tephra components and have an advantage over lava studies whereby rapid cooling of tephra allows preservation of magmatic equilibria between mineral phases and glasses, otherwise easily reset during slow cooling and even alteration in more slowly cooled rocks (e.g., magnetite-ilmenite equilibria; Bacon and Hirschmann, 1988).

Distal and ultra-distal tephra produced by strong plinian eruptions consists mostly of silicic glass shards (e.g., Davies, 2015). Rarity or complete absence of crystalline phases hampers significantly the use of distal tephras in traditional petrological applications (e.g., thermobarometry, melt inclusion studies) that require both analysis of glass (in matrix and melt inclusions) and minerals. As such, petrological and geochemical studies of distal tephra are largely narrowed to study of matrix glass composition. The development of analytical techniques having high spatial resolution (electron probe, ion probe, laser ablation ICP-MS) and working with very small (pg to ng) amounts of material (MC-TIMS, MC-ICPMS, laser fluorination) permits now matrix glass multi-element and isotope analysis with high precision comparable to bulk analytical techniques (e.g., Kimura et al., 2015; Koornneef et al., 2015). Thus, analytical problems of working with distal tephra are mostly solved now and even more progress is expected in the nearest future, which would allow routine analysis of glass microparticles for wide range of trace elements and isotope ratios.

Tephra glass can closely approach bulk composition of rarephyric and aphyric magma (e.g., Ponomareva et al., 2013b) or deviate strongly from bulk composition of porphyritic tephra samples (e.g., Melson, 1983; Ponomareva et al., 2015; Tomlinson et al., 2015). As such, distal tephra glasses cannot be used to reconstruct bulk magma compositions. Nevertheless, the glass represents composition of real melt existed at certain stage of magma evolution and therefore has the potential to provide valuable information about the source and magmatic conditions of explosive volcanism in the past. A common opinion, however, is that matrix tephra glasses represent residual melt after extensive magma crystallization and thus bear no or little information of parental melt at depth (e.g., Blundy and Cashman, 2008). To test this we carried out an analysis of published matrix glass compositions and melt inclusions in phenocrysts from a wide range of tephra samples. Melt inclusions enclosed in phenocrysts undoubtedly represent portions of deep melts (e.g., Wallace, 2005). Therefore, comparison of melt inclusions and matrix glasses is informative about the degree to which matrix glasses are evolved from melts existed in magma system at depth.

In Figure 3A, we compare matrix glasses and melt inclusions in plagioclase from tephras erupted by Mount St. Helens in 1980-1982 (Melson, 1983). A systematically more evolved (MgOpoor) composition of matrix glasses relative to melt inclusions is evident for samples representing blast facies, gray microlitebearing pumice and dome-building phase of the eruption. All these glasses are rich in microlites and can arguably represent late-stage melts, formed after substantial crystallization following phenocryst growth and melt inclusion entrapment. In contrast, microlite-free glasses and melt inclusions from white pumice representing the plinian phase of the 1980 eruption and also pumices erupted in $1800 \mathrm{AD}$ ( $\mathrm{T}$ pumice) and $1500 \mathrm{AD}$ (W pumice) have nearly identical compositions and therefore represent the same early stage of magma evolution. The only significant difference between melt inclusions and matrix glasses is lower $\mathrm{H}_{2} \mathrm{O}$ in the latter, which was degassed from magma 

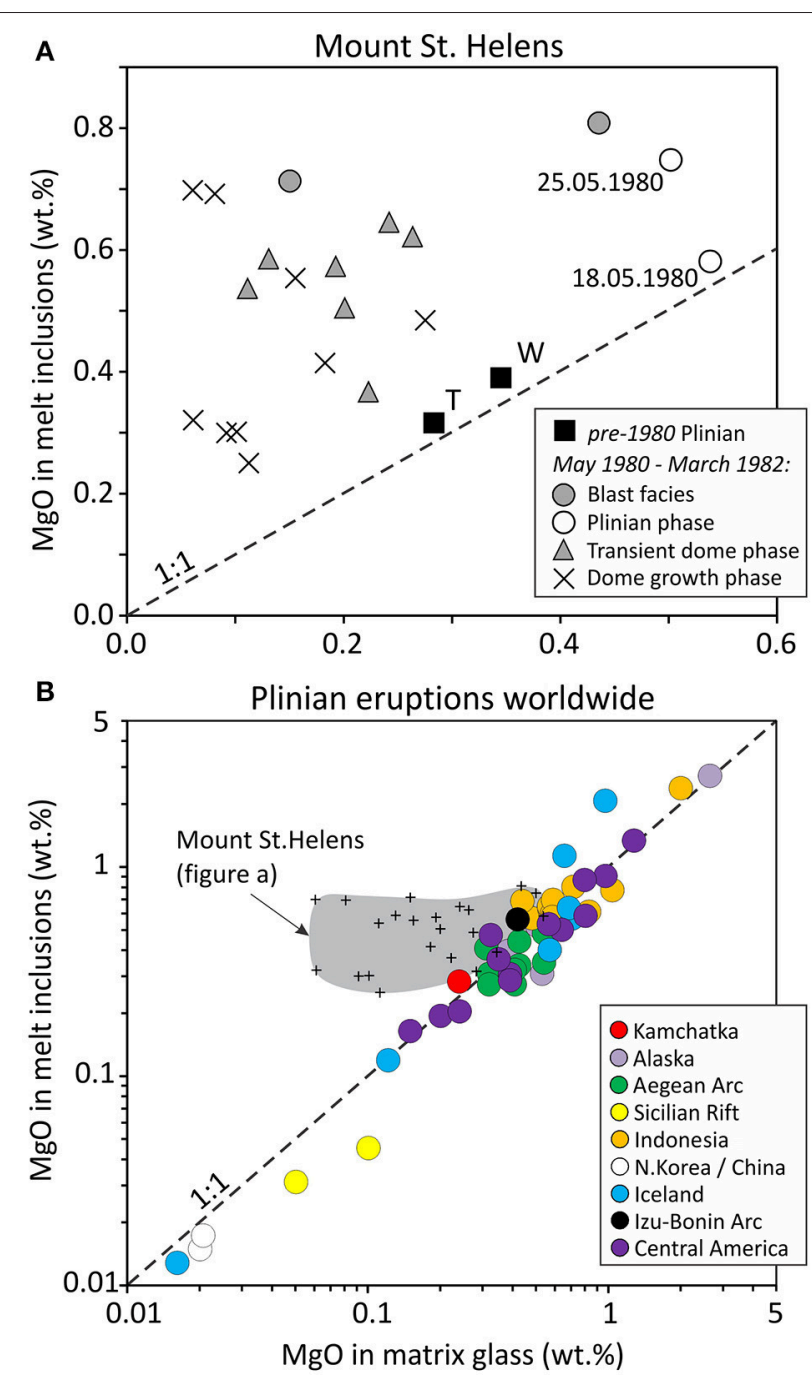

FIGURE 3 | Comparison of MgO content in matrix glasses and melt inclusions in minerals. (A) Data for different phases of Mount St. Helens 1980-1982 and pre-1980 eruptions (Melson, 1983); (B) Average MgO in matrix glasses and melt inclusions for 28 plinian eruptions woldwide. We show 55 matrix glass-melt inclusions pairs representing different eruptions, samples and different host minerals (plagioclase, alkali feldspar, olivine, amphibole, magnetite, quartz, clino- and orthopyroxene). Data are from Cadoux et al. (2014), Gioncada and Landi (2010), Horn and Schmincke (2000), Kutterolf et al. (2008a,b), Larsen (2006), Mandeville et al. (1996), Naumov et al. (2008), Plechov et al. (2010), Portnyagin et al. (2012), Schattel et al. (2014), Straub and Layne (2003b).

during the eruption (Melson, 1983). An apparent explanation for these observations is that magma ascent rate during the plinian phase was too high (time interval too short) for nucleation and growth of microlites in the matrix melt, while the magma degassed substantially.

In Figure 3B we compare matrix glasses and melt inclusions in different minerals for 28 plinian eruptions (55 pairs of matrix glass-inclusions) representing a wide range of geologic settings and magma types. In most cases, the compositions of matrix glasses and inclusions are very similar. Large differences are observed only for some mixed eruptions with wide range of matrix glasses and melt inclusions (e.g., Hekla 3; Sverrisdottir, 2007; Portnyagin et al., 2012). On the basis of these empirical observations we conclude that microlitefree matrix glasses of plinian eruptions have concentrations of non-volatile components approaching very closely those existed in melt prior to the eruptions. Far-traveled tephra are dispersed during plinian eruptions. Therefore, its matrix glass can be informative about geochemical peculiarities of melt and physicochemical conditions of its crystallization prior to eruption. Thus, geochemical analysis of distal tephra offers considerable insight into the composition and origin of parental melts for large-scale explosive volcanism on a regional scale.

In essence, the unique ability of single glass shards to preserve information on the melt crystallization conditions and on the geochemical peculiarity of magma sources makes geochemical fingerprinting possible. This application remains to be the most requested in tephrochronology. The relationships between composition of tephra glasses and magma storage conditions (pressure, temperature, oxygen fugacity, water activity) before eruption are not known in detail and need to be understood in future studies using available data from experimental petrology and geochemical modeling (e.g., Blundy and Cashman, 2008; Gualda et al., 2012; Gualda and Ghiorso, 2014). Because mineral assemblages are typically not preserved in distal tephra samples, the melt crystallization conditions cannot be estimated directly by application of two-mineral and mineral-melt thermobarometers (e.g., Anderson et al., 2008; Putirka, 2008). Alternative possibility is the use of liquidus thermobarometry, which requires knowledge of magma saturation in certain minerals and allows calculation of the conditions of its equilibrium with the melt of given composition (e.g., Roeder and Emslie, 1970; Nielsen and Dungan, 1983; Ariskin et al., 1993; Putirka, 2008; Lange et al., 2009). The methods of liquidus thermobarometry are well developed for basaltic glass compositions (e.g., Danyushevsky et al., 1996; Kelley and Barton, 2008) and are awaiting further elaboration for silicic systems commonly saturated in plagioclase - clinopyroxene - magnetite \pm ilmenite \pm amphibole \pm quartz \pm biotite. For example, Blundy and Cashman (2001) parametrized a barometer based on compositions of glasses, which can be used to constrain pressure of crystallization for melts saturated in quartz (minimum pressure for quartz-undersaturated melts). In our opinion, the studies of correlations between silicic melt (glass) composition and conditions of its equilibrium with minerals have considerable potential for improving our understanding of silicic magma origin and would pinpoint the most reliable and not just empirical but petrologically meaningful criteria for geochemical fingerprinting of tephra glass.

\section{FUTURE CHALLENGES AND PERSPECTIVES}

Although tephra studies provide important insight into past eruptions, there are also many challenges and considerations that 
are critical to optimize the application of this technique. Some of the key challenges that we face include:

(1) Post-depositional processes that can affect the stratigraphic integrity of a tephra and especially a cryptotephra deposit.

(2) Pinpointing diagnostic chemical glass signatures and establishing robust matches between different sites and the source volcano.

(3) Similar compositions of tephras from different eruptions from the same volcano.

(4) Inter-lab inconsistencies in producing and reporting analytical data.

(5) Post-depositional chemical alteration of volcanic glass.

(1) Cryptotephra deposits, in particular, are prone to the influence of post-depositional processes, e.g., bioturbation, bottom current reworking and iceberg rafting (see summary in Griggs et al., 2014). Such secondary processes can result in broad zones of high shard concentrations. The real stratigraphic position and age of such cryptotephras cannot be precisely established. Moreover, tephra could be stored in the ice sheets, especially in glacial times, and then deposited from icebergs hundreds of years after the eruption (e.g., Brendryen et al., 2011). Remobilization of tephra deposits in a volcanic area by storms or fluvial reworking could also form a secondary deposit which may be misidentified as a primary fallout deposit (e.g., Liu et al., 2014; Kataoka et al., in press). In these cases, redeposited tephra does not work as an isochron, and its thickness in its final landing site may bias isopach patterns. Protocols for the identification of primary vs. reworked deposits are thus crucial for reconstructing volcanic history as well as for utilizing these deposits as isochrones in palaeo-environmental studies (e.g., Hopkins et al., 2015).

(2) Tephrochronological studies have generated large analytical datasets of silicic and mafic volcanic glass (e.g., Smith et al., 2005, 2011a, 2013; Westgate et al., 2011; Tomlinson et al., 2012, 2015). The most important task is to uniquely identify a tephra deposit based on its composition and age, and compare one tephra to another to establish robust correlations between disparate sites (Lowe, 2011). Geochemical comparisons between different samples have been implemented with the help of more and more sophisticated statistical tools (Borchardt et al., 1972; Kutterolf et al., 2008a; Green et al., 2014; Bronk Ramsey et al., 2015b).

It is possible that tephras from different (or similar) tectonic settings but originating from different geographical regions (e.g., different island arcs) can be found in the same geological sequence (e.g., Lane et al., 2011; Cullen et al., 2014). A practical guide on discrimination of glasses from different tectonic settings has been recently developed for Mediterranean, Icelandic and Azores volcanoes (Tomlinson et al., 2015). However, a more general theoretic discrimination of tephras originating from different tectonic settings and from different volcanic regions is needed. It is unclear thus far if glasses from different volcanic regions are compositionally different enough to ensure their reliable discrimination and which major and trace elements and their ratios are the most informative for the discrimination.

Abundant geochemical information is available from studies of bulk volcanic rocks (high precision major and trace element data, isotope compositions, e.g., GEOROC database, http:/georoc.mpch-mainz.gwdg.de/georoc/). These data are rarely used in tephra studies. Is the information on bulk rock compositions indeed useless for tephrochronology? This is clearly not the case because volcanic glass represents the matrix of bulk rock and hosts elements which are incompatible in mineral phases. Radiogenic isotope ratios (e.g., $\mathrm{Pb}, \mathrm{Sr}, \mathrm{Nd}$ ) should be identical between bulk tephra and distal glass shards. The extent to which geochemical peculiarities of bulk rocks are inherited by volcanic glass need to be investigated systematically and for different rock types and regions. Some recent data suggest a very strong heterogeneity of volcanic glass compositions in one tephra (Westgate et al., 2013) and thus decoupling of glass and bulk rock compositions. The reason for this variability is not well understood and requires attention in future studies.

(3) As well as pinpointing diagnostic features for different volcanic regions and tectonic settings, the tephrochronological community also faces a challenge when different eruptions of the same source volcano produce identical glass compositions (e.g., Siani et al., 2004; Santacroce et al., 2008; Smith et al., 2011a; Kaufman et al., 2012; Lane et al., 2012; Wutke et al., 2015). These eruptions may be separated by hundreds or even thousands of years, but if these are close in age, it may cause erroneous identification and mis-correlation of a tephra. The existence of compositionally near steady-state longlived magma chambers in volcanically active areas is possible due to the periodic replenishment with more primitive magma, mixing, crystallization and eruption (e.g., O’Hara and Mathews, 1981; Lee et al., 2014). A search for diagnostic differences (for example, in isotope or non-traditional trace element composition, e.g., $\mathrm{Li}, \mathrm{B}, \mathrm{Cl}$ ) of such eruptions is a crucial challenge for future studies. Some constraints from modeling and natural observations are also required for our general understanding of the longevity of compositionally steady-state magma chambers and of the potential uncertainty in tephra identification introduced by this natural phenomenon.

(4) Inter-laboratory comparison exercises have long been undertaken between electron microprobe laboratories (e.g., Kuehn et al., 2011) to provide a robust assessment of the data quality. Some efforts have been also made to introduce standardized protocol for laser-ablation trace element analyses (e.g., Tomlinson et al., 2010; Pearce et al., 2014). However, in contrast to microprobe analysis, the analytical conditions and equipment used for trace element analysis of single glass shards vary considerably. Further work and joint discussion are required to establish a widely accepted protocol for tephra trace element analysis. In our opinion, such protocol should necessarily include 
the requirement to analyze well characterized and broadly available reference glasses and report detection limits estimated with a standardized procedure. This would enable a direct comparison of data obtained in different labs. At least one element with concentration determined by electron microprobe should be analyzed as unknown together with trace elements. Comparison of LA-ICP-MS and microprobe results for the same element permits evaluation of the consistency between major and trace element data and provides a quantitative criterion for rejection of analyses contaminated by crystal phases (Kimura et al., 2015). These obvious requirements have been adopted in solid-Earth geochemistry (e.g., Jenner and O'Neill, 2012) and are now required for routine analysis of single glass shards.

(5) In a study based on theoretical stability modeling of vitreous material Pollard et al. (2003) suggested that some volcanic glasses may be less stable than others in a given depositional environment, and may leach substantial amounts of alkali and alkaline earth elements, possibly from the entire volume of the tephra shards. Indeed, in hot and humid climates tephras can weather very quickly, within tens of thousands of years (e.g., Rawson et al., 2015). Many other researchers, however, confirm that volcanic glasses in marine and lake deposits as old as millions of years are quite fresh and have meaningful geochemical characteristics (e.g., van den Bogaard et al., 2014; Straub et al., 2015). In moderate and hot and dry climates Quaternary terrestrial tephras are also well preserved and suitable for geochemical analysis (e.g., WoldeGabriel et al., 2005; Kuehn and Negrini, 2010; Westgate et al., 2011). An assessment of postdepositional alteration is probably required on a site-specific basis.

All of these and many other problems of stratigraphic and geochemical credibility of tephra are being addressed in a wave of recent publications, particularly focused on the North Atlantic and Mediterranean regions. Not only do these studies outline the problems, but they also suggest possible approaches to overcome these issues. Multiple cores may help to fully explore the uneven nature of tephra distribution within different depositional realms (Davies, 2015) and recently applied visualization techniques (e.g., X-ray microtomography in Griggs et al., in press) also offer much promise in this respect. New developments in the analytical techniques permit analysis of a fuller range of major, volatile and trace elements from small tephra particles and melt inclusions

\section{REFERENCES}

Abbott, P. M., and Davies, S. M. (2012). Volcanism and the Greenland ice-cores: the tephra record. Earth Sci. Rev. 115, 173-191. doi: 10.1016/j.earscirev.2012.09.001

Abbott, P. M., Davies, S. M., Steffensen, J. P., Pearce, N. J. G., Bigler, M., Johnsen, S. J., et al. (2012). A detailed framework of Marine Isotope Stages 4 and 5 volcanic events recorded in two Greenland ice-cores. Quat. Sci. Rev. 36, 59-77. doi: 10.1016/j.quascirev.2011.05.001

Albert, P. G., Hardiman, M., Keller, J., Tomlinson, E. L., Smith, V. C., Bourne, A. J., et al. (2015). Revisiting the Y-3 tephrostratigraphic marker: a new diagnostic (e.g., Matsu'ura et al., 2011; Hayward, 2012; Pearce et al., 2014; Maruyama et al., in press).

Findings of distal tephra bring new information on earlier unrecognized large eruptions. They are helping to produce a better and more detailed record of the largest explosive eruptions than ever before and embedding these new data in tephra dispersal models and magma volume estimates provides new opportunities for quantifying eruption size. In addition, these new findings add more isochrons to a global tephrochronological framework which makes it possible to put more and more events into a tight stratigraphic and temporal context and for testing the synchronicity of major climatic shifts in different parts of the globe.

Tephra research has very quickly evolved into a global network of isochronous regional as well as hemispheric markers giving new insight into the prevailing pathways of tephra transport. Tephra deposits reveal that large explosive eruptions were a key feature of the past. Cryptotephra deposits reveal that there were many more large and far-traveled eruptions than previously realized (e.g., Coulter et al., 2012). Tephra crosses scientific disciplines, borders between land and sea, political borders and brings together multi-disciplinary research teams. New territories are being explored for their cryptotephra records (e.g., China, Sun et al., 2015; Zhao and Hall, 2015; Amazonia, Watson et al., 2015; Okhotsk and Bering Seas, Krasheninnikov et al., 2013), and there is no doubt that these efforts will result in a significant reappraisal of the power of past explosive eruptions and their temporal patterns, which will bring a better understanding of future volcanic events and their impact on humankind.

\section{ACKNOWLEDGMENTS}

The work on this paper was supported by the Russian Foundation for Basic Research (grant \#13-05-00346) and the Otto Schmidt Laboratory for Polar and Marine Research funded by the German Ministry of Science and Education (BMBF). The first draft of this paper was written during VP's stay at the University of Washington (Seattle), sponsored by the Quaternary Research Center; in particular, access to library resources was crucial for reviewing the abundant recent literature on tephra research. The authors greatly appreciate the detailed comments from Victoria Smith, Roberto Sulpizio, and David Pyle that significantly improved the manuscript. glass geochemistry, age estimate, and details on its climatostratigraphical context. Quat. Sci. Rev. 118, 105-121. doi: 10.1016/j.quascirev. 2014.04.002

Albert, P. G., Tomlinson, E. L., Smith, V. C., Di Roberto, A., Todman, A., Rosi, M., et al. (2012). Marine-continental tephra correlations: volcanic glass geochemistry from the Marsili Basin and the Aeolian Islands, Southern Tyrrhenian Sea, Italy. J. Volcanol. Geotherm. Res. 229-230, 74-94. doi: 10.1016/j.jvolgeores.2012.03.009

Allan, A. S. R., Baker, J. A., Carter, L., and Wysoczanksi, R. J. (2008). Reconstructing the Quaternary evolution of the world's most active silicic volcanic system: insights from an $\sim 1.65 \mathrm{Ma}$ deep ocean tephra record sourced 
from Taupo Volcanic Zone, New Zealand. Quat. Sci. Rev. 27, 2341-2360. doi: 10.1016/j.quascirev.2008.09.003

Alloway, B. V., Pillans, B. J., Carter, L., Naish, T. R., and Westgate, J. A. (2005). Onshore-offshore correlation of Pleistocene rhyolitic eruptions from New Zealand: implications for TVZ eruptive history and paleoenvironmental construction. Quat. Sci. Rev. 24, 1601-1622. doi: 10.1016/j.quascirev.2004.07.026

Anderson, J. L., Barth, A. P., Wooden, J. L., and Mazdab, F. (2008). Thermometers and thermobarometers in granitic systems. Rev. Mineral. Geochem. 69, 121-142. doi: 10.2138/rmg.2008.69.4

Arculus, R., Gill, J., Cambray, H., Chen, W., and Stern, R. (1995). Geochemical evolution of arc systems in the western Pacific: the ash and turbidite record recovered by drilling. Active Margins Marginal Basins West. Pac. 88, 78-101. doi: $10.1029 / g m 088$ p0045

Ariskin, A. A., Frenkel, M. Y., Barmina, G. S., and Nielsen, R. L. (1993). COMAGMAT: a Fortran program to model magma differentiation processes. Comput. Geosci. 19, 1155-1170. doi: 10.1016/0098-3004(93) 90020-6

Bacon, C. R., and Hirschmann, M. M. (1988). Mg/Mn partitioning as a test for equilibrium between coexisting Fe-Ti oxides. Am. Mineral. 73, 57-61.

Bindeman, I. N., Leonov, V. L., Izbekov, P. E., Ponomareva, V. V., Watts, K. E., Shipley, N. K., et al. (2010). Large-volume silicic volcanism in Kamchatka: $\mathrm{Ar}-\mathrm{Ar}$ and $\mathrm{U}-\mathrm{Pb}$ ages, isotopic, and geochemical characteristics of major preHolocene caldera-forming eruptions. J. Volcanol. Geotherm. Res. 189, 57-80. doi: 10.1016/j.jvolgeores.2009.10.009

Blockley, S. P., Bourne, A. J., Brauer, A., Davies, S. M., Hardiman, M., Harding, P. R., et al. (2014). Tephrochronology and the extended intimate (integration of ice-core, marine and terrestrial records) event stratigraphy 8-128 ka b2k. Quat. Sci. Rev. 106, 88-100. doi: 10.1016/j.quascirev.2014.11.002

Blundy, J., and Cashman, K. (2001). Ascent-driven crystallisation of dacite magmas at Mount St Helens, 1980-1986. Contrib. Mineral. Petrol. 140, 631-650. doi: $10.1007 / \mathrm{s} 004100000219$

Blundy, J., and Cashman, K. (2008). Petrologic reconstruction of magmatic system variables and processes. Rev. Mineral. Geochem. 69, 179-239. doi: 10.2138/rmg.2008.69.6

Bonadonna, C., and Costa, A. (2012). Estimating the volume of tephra deposits: a new simple strategy. Geology 40, 415-418. doi: 10.1130/G32769.1

Borchardt, G., Aruscavage, P., and Millard, H. Jr. (1972). Correlation of the Bishop Ash, a Pleistocene marker bed, using instrumental neutron activation analysis. J. Sediment. Res. 42, 301-306.

Bourne, A., Albert, P., Matthews, I., Trincardi, F., Wulf, S., Asioli, A., et al. (2015a). Tephrochronology of core PRAD 1-2 from the Adriatic Sea: insights into Italian explosive volcanism for the period 200-80 ka. Quat. Sci. Rev. 116, 28-43. doi: 10.1016/j.quascirev.2015.03.006

Bourne, A. J., Cook, E., Abbott, P. M., Seierstad, I. K., Steffensen, J. P., Svensson, A., et al. (2015b). A tephra lattice for Greenland and a reconstruction of volcanic events spanning 25-45 ka b2k. Quat. Sci. Rev. 118, 122-141. doi: 10.1016/j.quascirev.2014.07.017

Braitseva, O. A., Melekestsev, I. V., Ponomareva, V. V., and Sulerzhitsky, L. (1995). Ages of calderas, large explosive craters and active volcanoes in the Kuril-Kamchatka region, Russia. Bull. Volcanol. 57, 383-402.

Braitseva, O. A., Ponomareva, V. V., Sulerzhitsky, L. D., Melekestsev, I. V., and Bailey, J. (1997). Holocene key-marker tephra layers in Kamchatka, Russia. Quat. Res. 47, 125-139. doi: 10.1006/qres.1996.1876

Brendryen, J., Haflidason, H., and Sejrup, H. P. (2011). Non-synchronous deposition of North Atlantic Ash Zone II in Greenland ice cores, and North Atlantic and Norwegian Sea sediments: an example of complex glacial-stage tephra transport. J. Quat. Sci. 26, 739-745. doi: 10.1002/ jqs. 1499

Bronk Ramsey, C., Albert, P. G., Blockley, S. P. E., Hardiman, M., Housley, R. A., Lane, C. S., et al. (2015a). Improved age estimates for key Late Quaternary European tephra horizons in the RESET lattice. Quat. Sci. Rev. 118, 18-32. doi: 10.1016/j.quascirev.2014.11.007

Bronk Ramsey, C., Housley, R. A., Lane, C. S., Smith, V. C., and Pollard, A. M. (2015b). The RESET tephra database and associated analytical tools. Quat. Sci. Rev. 118, 33-47. doi: 10.1016/j.quascirev.2014.11.008

Brown, S., Crosweller, H., Sparks, R. S., Cottrell, E., Deligne, N., Guerrero, N., et al. (2014). Characterisation of the Quaternary eruption record: analysis of the
Large Magnitude Explosive Volcanic Eruptions (LaMEVE) database. J. Appl. Volcanol. 3:5. doi: 10.1186/2191-5040-3-5

Bryant, C. J., Arculus, R. J., and Eggins, S. M. (2003). The geochemical evolution of the Izu-Bonin arc system: a perspective from tephras recovered by deep-sea drilling. Geochem. Geophys. Geosys. 4:11. doi: 10.1029/2002gc000427

Cadoux, A., Scaillet, B., Druitt, T. H., and Deloule, E. (2014). Magma storage conditions of large plinian eruptions of Santorini volcano (Greece). J. Petrol. 55, 1129-1171. doi: 10.1093/petrology/egu021

Çağatay, M. N., Wulf, S., Sancar, Ü., Özmaral, A., Vidal, L., Henry, P., et al. (2015). The tephra record from the Sea of Marmara for the last ca. 70ka and its palaeoceanographic implications. Mar. Geol. 361, 96-110. doi: 10.1016/j.margeo.2015.01.005

Cambray, H., and Cadet, J. P. (1994). Testing global synchronism in peri-Pacific arc volcanism. J. Volcanol. Geotherm. Res. 63, 145-164. doi: 10.1016/03770273(94)90071-X

Cambray, H., and Cadet, J.-P. (1996). Synchronisme de l'activité volcanique d'arc: mythe ou réalité? Comptes Rendus de l'Académie des Sciences. Série 2. Sciences de la Terre et des Planètes 322, 237-244.

Cao, L.-Q, Arculus, R. J., and McKelvey, B. C. (1995). “Geochemistry and petrology of volcanic ashes recovered from sites 881 through 884: a temporal record of Kamchatka and Kurile volcanism," in Proceedings of the Ocean Drilling Program, Scientific Results, Vol. 145, eds D. K. Rea, I. A. Basov, D. W. Scholl, and J. F. Allan (College Station, TX: Ocean Drilling Program), 345-381.

Carey, R. J., Houghton, B. F., and Thordarson, T. (2010). Tephra dispersal and eruption dynamics of wet and dry phases of the 1875 eruption of Askja Volcano, Iceland. Bull. Volcanol. 72, 259-278. doi: 10.1007/s00445-009-0317-3

Caron, B., Sulpizio, R., Zanchetta, G., Siani, G., and Santacroce, R. (2010). The Late Holocene to Pleistocene tephrostratigraphic record of Lake Ohrid (Albania). C. R. Geosci. 342, 453-466. doi: 10.1016/j.crte.2010.03.007

Clift, P. D., Chan, L. H., Blusztajn, J., Layne, G. D., Kastner, M., and Kelly, R. K. (2005). Pulsed subduction accretion and tectonic erosion reconstructed since 2.5 Ma from the tephra record offshore Costa Rica. Geochem. Geophys. Geosys. 6:9. doi: 10.1029/2005gc000963

Clift, P. D., Layne, G. D., Najman, Y. M., Kopf, A., Shimizu, N., and Hunt, J. (2003). Temporal evolution of boron flux in the NE Japan and Izu arcs measured by ion microprobe from the forearc tephra record. J. Petrol. 44, 1211-1236. doi: 10.1093/petrology/44.7.1211

Costa, A., Folch, A., Macedonio, G., Giaccio, B., Isaia, R., and Smith, V. (2012). Quantifying volcanic ash dispersal and impact of the Campanian Ignimbrite super-eruption. Geophys. Res. Lett. 39, L10310. doi: 10.1029/2012 GL051605

Costa, A., Smith, V., Macedonio, G., and Matthews, N. (2014). The magnitude and impact of the Youngest Toba Tuff super-eruption. Front. Earth Sci. 2:16. doi: 10.3389/feart.2014.00016

Coulter, S. E., Pilcher, J. R., Plunkett, G., Baillie, M., Hall, V. A., Steffensen, J. P., et al. (2012). Holocene tephras highlight complexity of volcanic signals in Greenland ice cores. J. Geophys. Res. 117, D21303. doi: 10.1029/2012jd 017698

Coulter, S. E., Turney, C. S., Kershaw, P., and Rule, S. (2009). The characterization and significance of a MIS 5a distal tephra on mainland Australia. Quat. Sci. Rev. 28, 1825-1830. doi: 10.1016/j.quascirev.2009.04.018

Cullen, V. L., Smith, V. C., and Arz, H. W. (2014). The detailed tephrostratigraphy of a core from the south-east Black Sea spanning the last $\sim 60$ ?ka. J. Quat. Sci. 29, 675-690. doi: 10.1002/jqs.2739

Daggitt, M. L., Mather, T. A., Pyle, D. M., and Page, S. (2014). AshCalc-a new tool for the comparison of the exponential, power-law and Weibull models of tephra deposition. J. Appl. Volcanol. 3:7. doi: 10.1186/2191-5040-3-7

Dai, J., Mosley-Thompson, E., and Thompson, L. G. (1991). Ice core evidence for an explosive tropical volcanic eruption 6 years preceding Tambora. J. Geophys. Res. 96, 17361-17366. doi: 10.1029/91JD01634

Danyushevsky, L. V., Sobolev, A. V., and Dmitriev, L. V. (1996). Estimation of the pressure of crystallization and $\mathrm{H} 2 \mathrm{O}$ content of MORB and BABB glasses: calibration of an empirical technique. Mineral. Petrol. 57, 185-204.

Davies, S. M. (2015). Cryptotephras: the revolution in correlation and precision dating. J. Quat. Sci. 30, 114-130. doi: 10.1002/jqs.2766

Davies, S. M., Abbott, P. M., Meara, R. H., Pearce, N. J. G., Austin, W. E. N., Chapman, M. R., et al. (2014). A North Atlantic tephrostratigraphical framework for 130-60 ka b2k: new tephra discoveries, marine-based 
correlations, and future challenges. Quat. Sci. Rev. 106, 101-121. doi: 10.1016/j.quascirev.2014.03.024

Deligne, N., Coles, S., and Sparks, R. (2010). Recurrence rates of large explosive volcanic eruptions. J. Geophys. Res. Solid Earth 115. doi: 10.1029/2009jb006554

Delmonte, B., Andersson, P., Schöberg, H., Hansson, M., Petit, J., Delmas, R., et al. (2010). Geographic provenance of aeolian dust in East Antarctica during Pleistocene glaciations: preliminary results from Talos Dome and comparison with East Antarctic and new Andean ice core data. Quat. Sci. Rev. 29, 256-264. doi: 10.1016/j.quascirev.2009.05.010

Devine, J. D., Sigurdsson, H., Davis, A. N., and Self, S. (1984). Estimates of sulfur and chlorine yield to the atmosphere from volcanic eruptions and potential climatic effects. J. Geophys. Res. 89, 6309-6325 doi: 10.1029/jb089ib07p 06309

Donoghue, S. L., Vallance, J., Smith, I. E., and Stewart, R. B. (2007). Using geochemistry as a tool for correlating proximal andesitic tephra: case studies from Mt Rainier (USA) and Mt Ruapehu (New Zealand). J. Quat. Sci. 22, 395-410. doi: 10.1002/jqs.1065

Dunbar, N. W., and Kurbatov, A. V. (2011). Tephrochronology of the Siple Dome ice core, West Antarctica: correlations and sources. Quat. Sci. Rev. 30, 1602-1614. doi: 10.1016/j.quascirev.2011.03.015

Firth, C., Handley, H., Cronin, S., and Turner, S. (2014). The eruptive history and chemical stratigraphy of a post-caldera, steady-state volcano: Yasur, Vanuatu. Bull. Volcanol. 76, 1-23. doi: 10.1007/s00445-014-0837-3

Fontijn, K., Costa, F., Sutawidjaja, I., Newhall, C., and Herrin, J. (2015). A 5000-year record of multiple highly explosive mafic eruptions from Gunung Agung (Bali, Indonesia): implications for eruption frequency and volcanic hazards. Bull. Volcanol. 77, 1-15. doi: 10.1007/s00445-0150943-x

Garrison, V. H., Shinn, E. A., Foreman, W. T., Griffin, D. W., Holmes, C. W., Kellogg, C. A., et al. (2003). African and Asian dust: from desert soils to coral reefs. BioScience 53, 469-480. doi: 10.1641/00063568(2003)053[0469:AAADFD]2.0.CO;2

Gioncada, A., and Landi, P. (2010). The pre-eruptive volatile contents of recent basaltic and pantelleritic magmas at Pantelleria (Italy). J. Volcanol. Geotherm. Res. 189, 191-201. doi: 10.1016/j.jvolgeores.2009.11.006

Green, R. M., Bebbington, M. S., Cronin, S. J., and Jones, G. (2014). Automated statistical matching of multiple tephra records exemplified using five long maar sequences younger than 75 ka, Auckland, New Zealand. Quat. Res. 82, 405-419. doi: 10.1016/j.yqres.2014.06.004

Griggs, A. J., Davies, S. M., Abbott, P. M., Coleman, M., Palmer, A. P., Rasmussen, T. L., et al. (in press). Visualizing tephra deposits and sedimentary processes in the marine environment: the potential of X-ray microtomography. Geochem. Geophys. doi: 10.1002/2015gc006073

Griggs, A. J., Davies, S. M., Abbott, P. M., Rasmussen, T. L., and Palmer, A. P. (2014). Optimising the use of marine tephrochronology in the North Atlantic: a detailed investigation of the Faroe Marine Ash Zones II, III and IV. Quat. Sci. Rev. 106, 122-139. doi: 10.1016/j.quascirev.2014.04.031

Gualda, G. A. R., Ghiorso, M. S., Lemons, R. V., and Carley, T. L. (2012). Rhyolite-MELTS: a modified calibration of MELTS optimized for silica-rich, fluid-bearing magmatic systems. J. Petrol. 53, 875-890. doi: 10.1093/petrology/egr080

Gualda, G. R., and Ghiorso, M. (2014). Phase-equilibrium geobarometers for silicic rocks based on rhyolite-MELTS. Part 1: principles, procedures, and evaluation of the method: Contrib. Mineral. Petrol. 168, 1-17. doi: 10.1007/s00410-0141033-3

Gudmundsdóttir, E. R., Larsen, G., and Eiríksson, J. (2011). Two new Icelandic tephra markers: the Hekla Ö tephra layer, 6060 cal. yr BP, and Hekla DH tephra layer, $\sim 6650$ cal. yr BP. Land-sea correlation of mid-Holocene tephra markers. Holocene 21, 629-639. doi: 10.1177/0959683610391313

Gudmundsdóttir, E. R., Larsen, G., and Eiríksson, J. (2012). Tephra stratigraphy on the North Icelandic shelf: extending tephrochronology into marine sediments off North Iceland. Boreas 41, 719-734. doi: 10.1111/j.1502-3885.2012.00258.x

Gudmundsson, M. T., Thordarson, T., Höskuldsson, Á., Larsen, G., Björnsson, H., Prata, F. J., et al. (2012). Ash generation and distribution from the April-May 2010 eruption of Eyjafjallajökull, Iceland. Sci. Rep. 2:572. doi: 10.1038/srep00572

Gusev, A. A., Ponomareva, V. V., Braitseva, O. A., Melekestsev, I. V., and Sulerzhitsky, L. D. (2003). Great explosive eruptions on Kamchatka during the last 10,000 years: self-similar irregularity of the output of volcanic products J. Geophys. Res. 108:2126. doi: 10.1029/2001jb000312

Hammer, J. E., Cashman, K. V., Hoblitt, R. P., and Newman, S. (1999). Degassing and microlite crystallization during pre-climactic events of the 1991 eruption of Mt. Pinatubo, Philippines. Bull. Volcanol. 60, 355-380. doi: 10.1007/s004450050238

Hart, D., and Miller, D. J. (2006). "Analysis and correlation of volcanic ash in marine sediments from the Peru margin, Ocean Drilling Program Leg 201: explosive volcanic cycles of the north-central Andes," in Proceedings of the Ocean Drilling Program, Scientific Results, Vol. 21, eds B. B. Jørgensen, S. L. D’Hondt, and D. J. Miller (College Station, TX: Ocean Drilling Program), 1-43. doi: 10.2973/odp.proc.sr.201.122.2006

Hasegawa, T., Nakagawa, M., Yoshimoto, M., Ishizuka, Y., Hirose, W., Seki, S.I., et al. (2011). Tephrostratigraphy and petrological study of Chikurachki and Fuss volcanoes, western Paramushir Island, northern Kurile Islands: evaluation of Holocene eruptive activity and temporal change of magma system. Quat. Int. 246, 278-297. doi: 10.1016/j.quaint.2011.06.047

Hayward, C. (2012). High spatial resolution electron probe microanalysis of tephras and melt inclusions without beam-induced chemical modification. Holocene 22, 119-125. doi: 10.1177/0959683611409777

Holt, K. A., Lowe, D. J., Hogg, A. G., and Wallace, R. C. (2011). Distal occurrence of mid-Holocene Whakatane Tephra on the Chatham Islands, New Zealand, and potential for cryptotephra studies. Quat. Int. 246, 344-351. doi: 10.1016/j.quaint.2011.06.026

Hopkins, J. L., Millet, M.-A., Timm, C., Wilson, C. J., Leonard, G. S., Palin, J. M., et al. (2015). Tools and techniques for developing tephra stratigraphies in lake cores: a case study from the basaltic Auckland Volcanic Field, New Zealand. Quat. Sci. Rev. 123, 58-75. doi: 10.1016/j.quascirev.2015. 06.014

Horn, S., and Schmincke, H.-U. (2000). Volatile emission during the eruption of Baitoushan Volcano (China/North Korea) ca. 969 AD. Bull. Volcanol. 61, 537-555. doi: 10.1007/s004450050004

Hughes, G. R., and Mahood, G. A. (2008). Tectonic controls on the nature of large silicic calderas in volcanic arcs. Geology 36, 627-630. doi: 10.1130/G24 796A.1

Iverson, N. A., Kyle, P. R., Dunbar, N. W., McIntosh, W. C., and Pearce, N. J. (2014). Eruptive history and magmatic stability of Erebus volcano, Antarctica: insights from englacial tephra. Geochem. Geophys. Geosys. 15, 4180-4202. doi: 10.1002/2014GC005435

Jenner, F. E., and O'Neill, H. S. C. (2012). Major and trace analysis of basaltic glasses by laser-ablation ICP-MS. Geochem. Geophys. Geosys. 13, Q03003, doi: 10.1029/2011gc003890

Jensen, B. J. L., Pyne-O’Donnell, S., Plunkett, G., Froese, D. G., Hughes, P. D. M., Sigl, M., et al. (2014). Transatlantic distribution of the Alaskan White River Ash. Geology 42, 875-878. doi: 10.1130/G35945.1

Jensen, B. J., Reyes, A. V., Froese, D. G., and Stone, D. B. (2013). The Palisades is a key reference site for the middle Pleistocene of eastern Beringia: new evidence from paleomagnetics and regional tephrostratigraphy. Quat. Sci. Rev. 63, 91-108. doi: 10.1016/j.quascirev.2012.11.035

Johnston, E. N., Phillips, J. C., Bonadonna, C., and Watson, I. M. (2012). Reconstructing the tephra dispersal pattern from the Bronze Age eruption of Santorini using an advection-diffusion model. Bull. Volcanol. 74, 1485-1507. doi: 10.1007/s00445-012-0609-x

Johnston, E. N., Sparks, R. S. J., Phillips, J. C., and Carey, S. (2014). Revised estimates for the volume of the Late Bronze Age Minoan eruption, Santorini, Greece. J. Geol. Soc. 171, 583-590. doi: 10.1144/jgs2013-113

Kandlbauer, J., and Sparks, R. S. J. (2014). New estimates of the 1815 Tambora eruption volume. J. Volcanol. Geotherm. Res. 286, 93-100. doi: 10.1016/j.jvolgeores.2014.08.020

Kataoka, K. S., Urabe, A., and Nagahashi, Y. (in press). Millennial-scale reworking of tephra in alluvial to shallow marine settings: distinguishing pseudoisochrons from genuine ones. Quat. Int. doi: 10.1016/j.quaint.2015.03.022. [Epub ahead of print].

Kaufman, D. S., Jensen, B. J., Reyes, A. V., Schiff, C. J., Froese, D. G., and Pearce, N. J. (2012). Late Quaternary tephrostratigraphy, Ahklun Mountains, SW Alaska. J. Quat. Sci. 27, 344-359. doi: 10.1002/jqs.1552

Kelley, D. F., and Barton, M. (2008). Pressures of crystallization of Icelandic magmas. J. Petrol. 49, 465-492. doi: 10.1093/petrology/egm089 
Kimura, J.-I., Nagahashi, Y., Satoguchi, Y., and Chang, Q. (2015). Origins of felsic magmas in Japanese subduction zone: geochemical characterizations of tephra from caldera-forming eruptions $<5 \mathrm{Ma}$. Geochem. Geophys. Geosys. 16, 2147-2174. doi: 10.1002/2015gc005854

Koornneef, J. M., Nikogosian, I., van Bergen, M. J., Smeets, R., Bouman, C, and Davies, G. R. (2015). TIMS analysis of $\mathrm{Sr}$ and Nd isotopes in melt inclusions from Italian potassium-rich lavas using prototype $1013 \Omega$ amplifiers. Chem. Geol. 397, 14-23, doi: 10.1016/j.chemgeo.2015.01.005

Krasheninnikov, S., Ponomareva, V., Portnyagin, M., Bubenschikova, N., Ovsepyan, E., and Nürnberg, D. (2013). First Data on Cryptotephra in Okhotsk and Bering Seas Sediments: XX International Scientific Conference (School) on Marine Geology. Moscow. Available online at: http://geoschool.ocean.ru/index. $\mathrm{php} /$ materialy-konferentsii.html [In Russian].

Kuehn, S., Froese, D., Shane, P., and Participants, I. I. (2011). The INTAV intercomparison of electron-beam microanalysis of glass by tephrochronology laboratories: results and recommendations. Quat. Int. 246, 19-47. doi: 10.1016/j.quaint.2011.08.022

Kuehn, S. C., and Negrini, R. M. (2010). A 250 k.y. record of Cascade arc pyroclastic volcanism from late Pleistocene lacustrine sediments near Summer Lake, Oregon, USA. Geosphere 6, 397-429. doi: 10.1130/GES00515.1

Kurbatov, A. V., Zielinski, G., Dunbar, N., Mayewski, P. A., Meyerson, E., Sneed, S. B., et al. (2006). A 12,000 year record of explosive volcanism in the Siple Dome Ice Core, West Antarctica. J. Geophys. Res. 111, D12307. doi: 10.1029/2005jd006072

Kutterolf, S., Freundt, A., and Perez, W. (2008b). Pacific offshore record of plinian arc volcanism in Central America: 2. Tephra volumes and erupted masses. Geochem. Geophys. Geosys. 9:Q02S02. doi: 10.1029/2007gc001791

Kutterolf, S., Freundt, A., Perez, W., Morz, T., Schacht, U., Wehrmann, H., et al. (2008a). Pacific offshore record of plinian arc volcanism in Central America: 1. Along-arc correlations. Geochem. Geophys. Geosys. 9:Q02S01. doi: 10.1029/2007gc001631

Kutterolf, S., Hansteen, T. H., Appel, K., Freundt, A., Krüger, K., Pérez, W., et al. (2013a). Combined bromine and chlorine release from large explosive volcanic eruptions: a threat to stratospheric ozone? Geology 41, 707-710. doi: $10.1130 / \mathrm{G} 34044.1$

Kutterolf, S., Hansteen, T. H., Freundt, A., Wehrmann, H., Appel, K., Krüger, K., et al. (2015). Bromine and chlorine emissions from Plinian eruptions along the Central American Volcanic Arc: from source to atmosphere. Earth Planet. Sci. Lett. 429:234-246. doi: 10.1016/j.epsl.2015.07.064

Kutterolf, S., Jegen, M., Mitrovica, J. X., Kwasnitschka, T., Freundt, A., and Huybers, P. J. (2013b). A detection of Milankovitch frequencies in global volcanic activity. Geology 41, 227-230. doi: 10.1130/G33419.1

Lacasse, C., and Garbe-Schönberg, C.-D. (2001). Explosive silicic volcanism in Iceland and the Jan Mayen area during the last $6 \mathrm{Ma}$ : sources and timing of major eruptions. J. Volcanol. Geotherm. Res. 107, 113-147. doi: 10.1016/S03770273(00)00299-7

Lane, C. S., Andriè, M., Cullen, V. L., and Blockley, S. P. (2011). The occurrence of distal Icelandic and Italian tephra in the Lateglacial of Lake Bled, Slovenia. Quat. Sci. Rev. 30, 1013-1018. doi: 10.1016/j.quascirev.2011.02.014

Lane, C. S., Blockley, S. P., Mangerud, J., Smith, V. C., Lohne, Ø. S., Tomlinson, E., et al. (2012). Was the 12.1 ka Icelandic Vedde Ash one of a kind? Quat. Sci. Rev. 33, 87-99. doi: 10.1016/j.quascirev.2011.11.011

Lane, C. S., Brauer, A., Blockley, S. P., and Dulski, P. (2013a). Volcanic ash reveals time-transgressive abrupt climate change during the Younger Dryas. Geology 41, 1251-1254. doi: 10.1130/G34867.1

Lane, C. S., Brauer, A., Martín-Puertas, C., Blockley, S. P. E., Smith, V. C., and Tomlinson, E. L. (2015). The Late Quaternary tephrostratigraphy of annually laminated sediments from Meerfelder Maar, Germany. Quat. Sci. Rev. 122, 192-206. doi: 10.1016/j.quascirev.2015.05.025

Lane, C. S., Chorn, B. T., and Johnson, T. C. (2013b). Ash from the Toba supereruption in Lake Malawi shows no volcanic winter in East Africa at 75 ka. Proc. Nat. Acad. Sci. U.S.A. 110, 8025-8029. doi: 10.1073/pnas.1301474110

Lane, C. S., Cullen, V. L., White, D., Bramham-Law, C. W. F., and Smith, V. C. (2014). Cryptotephra as a dating and correlation tool in archaeology. J. Archaeol. Sci. 42, 42-50. doi: 10.1016/j.jas.2013.10.033

Lange, R. A., Frey, H. M., and Hector, J. (2009). A thermodynamic model for the plagioclase-liquid hygrometer/thermometer. Am. Mineral. 94, 494-506. doi: 10.2138/am.2009.3011
Larsen, J. F. (2006). Rhyodacite magma storage conditions prior to the 3430 y BP caldera-forming eruption of Aniakchak volcano, Alaska. Contrib. Mineral. Petrol. 152, 523-540. doi: 10.1007/s00410006-0121-4

Lavigne, F., Degeai, J.-P., Komorowski, J.-C., Guillet, S., Robert, V., Lahitte, P., et al. (2013). Source of the great A.D. 1257 mystery eruption unveiled, Samalas volcano, Rinjani Volcanic Complex, Indonesia. Proc. Natl. Acad. Sci. U.S.A. 110, 16742-16747. doi: 10.1073/pnas.1307520110

Lawson, I. T., Swindles, G. T., Plunkett, G., and Greenberg, D. (2012). The spatial distribution of Holocene cryptotephras in north-west Europe since $7 \mathrm{ka}$ implications for understanding ash fall events from Icelandic eruptions. Quat. Sci. Rev. 41, 57-66. doi: 10.1016/j.quascirev.2012.02.018

Lee, C. T. A., Lee, T. C., and Wu, C. T. (2014). Modeling the compositional evolution of recharging, evacuating, and fractionating (REFC) magma chambers: implications for differentiation of arc magmas. Geochim. Cosmochim. Acta 143, 8-22. doi: 10.1016/j.gca.2013.08.009

Lim, C., Lee, I., and Ikehara, K. (2013). Geochemical identification of cryptotephras using INAA from Late Quaternary hemipelagic sediments, southwest Japan. Mar. Geol. 346, 233-245. doi: 10.1016/j.margeo.2013.09.013

Liu, E., Cashman, K., Beckett, F., Witham, C., Leadbetter, S., Hort, M., et al. (2014). Ash mists and brown snow: remobilization of volcanic ash from recent Icelandic eruptions. J. Geophys. Res. 119, 9463-9480. doi: 10.1002/2014JD021598

Loughlin, S., Sparks, S., Brown, S., Jenkins, S., and Vye-Brown, C. (Eds.). (2015). Global Volcanic Hazards and Risk. Cambridge, UK: Cambridge University Press, 408.

Lowe, D., and Alloway, B. (2014). "Tephrochronology.[Chapter 19]," in Encyclopaedia of Scientific Dating Methods, eds W. J. Rink and J. Thompson (Dordrecht: Springer), 1-26.

Lowe, D. J. (2011). Tephrochronology and its application: a review. Quat. Geochronol. 6, 107-153. doi: 10.1016/j.quageo.2010.08.003

Lowe, D. J., Blaauw, M., Hogg, A. G., and Newnham, R. M. (2013). Ages of 24 widespread tephras erupted since 30,000 years ago in New Zealand, with reevaluation of the timing and palaeoclimatic implications of the Lateglacial cool episode recorded at Kaipo bog. Quat. Sci. Rev. 74, 170-194. doi: 10.1016/j.quascirev.2012.11.022

Lowe, D. J., and Hunt, J. B. (2001). "A summary of terminology used in tephrarelated studies," in Tephras: Chronology, Archaeology, Vol. 1, eds E. T Juvigné, J.-P. Raynal (CDERAD editeur) (Gaudet: Les Dossiers de I'Archéo-Logis), $17-22$.

Lowe, J., Barton, N., Blockley, S., Ramsey, C. B., Cullen, V. L., Davies, W. et al. (2012). Volcanic ash layers illuminate the resilience of Neanderthals and early modern humans to natural hazards. Proc. Natl. Acad. Sci. U.S.A. 109, 13532-13537. doi: 10.1073/pnas.1204579109

Mahony, S. H., Sparks, R. S. J., and Barnard, N. H. (2014). Quantifying uncertainties in marine volcanic ash layer records from ocean drilling cores. Mar. Geol. 357, 218-224. doi: 10.1016/j.margeo.2014.08.010

Mandeville, C. W., Carey, S., and Sigurdsson, H. (1996). Magma mixing, fractional crystallization and volatile degassing during the 1883 eruption of Krakatau volcano, Indonesia. J. Volcanol. Geotherm. Res. 74, 243-274. doi: 10.1016/S0377-0273(96)00060-1

Maruyama, S., Hattori, K., Hirata, T., and Danhara, T. (in press). A proposed methodology for analyses of wide-ranged elements in volcanic glass shards in widespread Quaternary tephras. Quat. Int. doi: 10.1016/j.quaint.2015.06.020. [Epub ahead of print].

Matsu'ura, T., Ueno, T., and Furusawa, A. (2011). Characterization and correlation of cryptotephras using major-element analyses of melt inclusions preserved in quartz in last interglacial marine sediments, southeastern Shikoku, Japan. Quat. Int. 246, 48-56. doi: 10.1016/j.quaint.2011. 03.017

Melson, W. G. (1983). Monitoring the 1980-1982 Eruptions of Mount St Helens: compositions and Abundances of Glass. Science 221, 1387-1391. doi: 10.1126/science.221.4618.1387

Metzner, D., Kutterolf, S., Toohey, M., Timmreck, C., Niemeier, U., Freundt, A., et al. (2014). Radiative forcing and climate impact resulting from $\mathrm{SO}_{2}$ injections based on a 200,000-year record of Plinian eruptions along the Central American Volcanic Arc. Int. J. Earth Sci. 103, 2063-2079. doi: 10.1007/s00531-012 0814-z 
Miller, T. P., and Smith, R. L. (1987). Late Quaternary caldera-forming eruptions in the eastern Aleutian arc, Alaska. Geology 15, 434-438.

Narcisi, B., Petit, J. R., and Delmonte, B. (2010). Extended East Antarctic ice-core tephrostratigraphy. Quat. Sci. Rev. 29, 21-27. doi: 10.1016/j.quascirev.2009.07.009

Narcisi, B., Petit, J. R., Delmonte, B., Scarchilli, C., and Stenni, B. (2012). A 16,000-yr tephra framework for the Antarctic ice sheet: a contribution from the new Talos Dome core. Quat. Sci. Rev. 49, 52-63. doi: 10.1016/j.quascirev.2012.06.011

Naumov, V. B., Tolstykh, M. L., Grib, E. N., Leonov, V. L., and Kononkova, N. N. (2008). Chemical composition, volatile components, and trace elements in melts of the Karymskii volcanic center, Kamchatka, and Golovnina volcano, Kunashir Island: evidence from inclusions in minerals. Petrology 16, 1-18. doi: 10.1134/S0869591108010013

Newhall, C. G., and Self, S. (1982). The volcanic explosivity index (VEI) an estimate of explosive magnitude for historical volcanism. J. Geophys. Res. 87, 1231-1238. doi: 10.1029/JC087iC02p01231

Nielsen, R. L., and Dungan, M. A. (1983). Low pressure mineral-melt equilibria in natural anhydrous mafic system. Contrib. Mineral. Petrol. 84, 310-326. doi: 10.1007/BF01160284

O'Hara, M. J., and Mathews, R. E. (1981). Geochemical evolution in an advancing, periodically replenished, periodically tapped, continuously fractionated magma chamber. J. Geol. Soc. 138, 237-277. doi: 10.1144/gsigs. 138.3.0237

Okuno, M., Torii, M., Yamada, K., Shinozuka, Y., Danhara, T., Gotanda, K., et al. (2011). Widespread tephras in sediments from lake Ichi-no-Megata in northern Japan: their description, correlation and significance. Quat. Int. 246, 270-277. doi: 10.1016/j.quaint.2011.08.015

Óladóttir, B., Larsen, G., and Sigmarsson, O. (2011a). Holocene volcanic activity at Grímsvötn, Bárdarbunga and Kverkfjöll subglacial centres beneath Vatnajökull, Iceland. Bull. Volcanol. 73, 1187-1208. doi: 10.1007/s00445-0110461-4

Óladóttir, B. A., Larsen, G., and Sigmarsson, O. (2012). Deciphering eruption history and magmatic processes from tephra in Iceland. Jökull 62, 21-38.

Óladóttir, B. A., Sigmarsson, O., Larsen, G., and Devidal, J.-L. (2011b). Provenance of basaltic tephra from Vatnajökull subglacial volcanoes, Iceland, as determined by major- and trace-element analyses. Holocene 21, 1037-1048. doi: $10.1177 / 0959683611400456$

Óladóttir, B. A., Sigmarsson, O., Larsen, G., and Thordarson, T. (2008). Katla volcano, Iceland: magma composition, dynamics and eruption frequency as recorded by Holocene tephra layers. Bull. Volcanol. 70, 475-493. doi: 10.1007/s00445-007-0150-5

Oppenheimer, C. (2003). Climatic, environmental and human consequences of the largest known historic eruption: tambora volcano (Indonesia) 1815. Progr. Phys. Geogr. 27, 230-259. doi: 10.1191/0309133303pp379ra

Oxford Economics (2010). The Economic Impacts of Air Travel Restrictions Due to Volcanic Ash, Report. Oxford: Abbey House.

Park, M. H., Kim, I. S., and Shin, J. B. (2003). Characteristics of the late Quaternary tephra layers in the East/Japan Sea and their new occurrences in western Ulleung Basin sediments. Mar. Geol. 202, 135-142. doi: 10.1016/S00253227(03)00287-1

Paterne, M., Guichard, F., Duplessy, J. C., Siani, G., Sulpizio, R., and Labeyrie, J. (2008). A 90,000-200,000 yrs marine tephra record of Italian volcanic activity in the central Mediterranean Sea. J. Volcanol. Geotherm. Res. 177, 187-196. doi: 10.1016/j.jvolgeores.2007.11.028

Paterne, M., Labeyrie, J., Guichard, F., Mazaud, A., and Maitre, F. (1990). Fluctuation of the campanian explosive activity (South Italy) during the past 190,000 years as determined by marine tephrochronology. Earth Planet. Sci. Lett. 98, 166-174. doi: 10.1016/0012-821X(90) 90057-5

Pearce, N. J., Abbott, P. M., and Martin-Jones, C. (2014). Microbeam methods for the analysis of glass in fine-grained tephra deposits: a SMART perspective on current and future trends. Geol. Soc. Lond. Spec. Publ. 398, 29-46. doi: 10.1144/SP398.1

Pearce, N. J., Westgate, J. A., Preece, S. J., Eastwood, W. J., and Perkins, W. T. (2004). Identification of Aniakchak (Alaska) tephra in Greenland ice core challenges the $1645 \mathrm{BC}$ date for Minoan eruption of Santorini. Geochem. Geophys. Geosys. 5:Q03005. doi: 10.1029/2003gc000672
Plechov, P. Y., Balashova, A. L., and Dirksen, O. V. (2010). Magma degassing during 7600 14C Kurile Lake caldera-forming eruption and its climatic impact. Doklady Earth Sci. 433, 974-977. doi: 10.1134/S1028334X10070275

Pollard, A. M., Blockley, S. P. E., and Ward, K. R. (2003). Chemical alteration of tephra in the depositional environment: theoretical stability modelling. J. Quat. Sci. 18, 385-394. doi: 10.1002/jqs.760

Ponomareva, V., Kyle, P., Melekestsev, I., Rinkleff, P., Dirksen, O., Sulerzhitsky, L., et al. (2004). The 7600 (14 C) year BP Kurile Lake caldera-forming eruption, Kamchatka, Russia: stratigraphy and field relationships. J. Volcanol. Geotherm. Res. 136, 199-222. doi: 10.1016/j.jvolgeores.2004.05.013

Ponomareva, V., Portnyagin, M., Derkachev, A., Juschus, O., Garbe-Schönberg, D., and Nürnberg, D. (2013a). Identification of a widespread Kamchatkan tephra: a middle Pleistocene tie-point between Arctic and Pacific paleoclimatic records. Geophys. Res. Lett. 40, 3538-3543. doi: 10.1002/grl.50645

Ponomareva, V., Portnyagin, M., Derkachev, A., Pandea, I. F., Bourgeois, J., Krasheninnikov, S., et al. (2013b). Early Holocene M 6 explosive eruption from Ushkovsky volcano (Kamchatka) and its tephra as a link between terrestrial and marine paleoenvironmental records. Int. J. Earth Sci. 102, 1673-1699. doi: 10.1007/s00531-013-0898-0

Ponomareva, V., Portnyagin, M., Pevzner, M., Blaauw, M., Kyle, P., and Derkachev, A. (2015). Tephra from andesitic Shiveluch volcano, Kamchatka, NW Pacific: chronology of explosive eruptions and geochemical fingerprinting of volcanic glass. Int. J. Earth Sci. 104, 1459-1482. doi: 10.1007/s00531-0151156-4

Portnyagin, M., Hoernle, K., Storm, S., Mironov, N., van den Bogaard, C., and Botcharnikov, R. (2012). $\mathrm{H}_{2} \mathrm{O}$-rich melt inclusions in fayalitic olivine from Hekla volcano: implications for phase relationships in silicic systems and driving forces of explosive volcanism on Iceland. Earth Planet. Sci. Lett. 357-358, 337-346. doi: 10.1016/j.epsl.2012.09.047

Preece, S. J., Pearce, N. J. G., Westgate, J. A., Froese, D. G., Jensen, B. J. L., and Perkins, W. T. (2011). Old Crow tephra across eastern Beringia: a single cataclysmic eruption at the close of Marine Isotope Stage 6. Quat. Sci. Rev. 30, 2069-2090. doi: 10.1016/j.quascirev.2010.04.020

Prueher, L. M., and Rea, D. K. (2001). Tephrochronology of the Kamchatka-Kurile and Aleutian arcs: evidence for volcanic episodicity. J. Volcanol. Geotherm. Res. 106, 67-84. doi: 10.1016/S0377-0273(00)00266-3

Putirka, K. D. (2008). Thermometers and barometers for volcanic systems. Rev. Mineral. Geochem. 69, 61-120. doi: 10.2138/rmg.2008.69.3

Pyle, D. M. (1995). Mass and energy budgets of explosive volcanic eruptions. Geophys. Res. Lett. 22, 563-566. doi: 10.1029/95GL00052

Pyle, D. M. (2000). "Sizes of volcanic eruptions", in Encyclopedia of Volcanoes, eds H. Sigurdsson, B. Houghton, H. Rymer, J. Stix, and S. McNutt (London: Academic Press), 263-269.

Pyne-O'Donnell, S. D. F., Hughes, P. D. M., Froese, D. G., Jensen, B. J. L., Kuehn, S. C., Mallon, G., et al. (2012). High-precision ultra-distal Holocene tephrochronology in North America. Quat. Sci. Rev. 52, 6-11. doi: 10.1016/j.quascirev.2012.07.024

Rawson, H., Naranjo, J. A., Smith, V., Fontijn, K., Pyle, D. M., Mather, T. A., et al. (2015). The frequency and magnitude of post-glacial explosive eruptions at Volcán Mocho-Choshuenco, southern Chile. J. Volcanol. Geotherm. Res. 299, 103-129. doi: 10.1016/j.jvolgeores.2015.04.003

Riede, F., and Thastrup, M. B. (2013). Tephra, tephrochronology and archaeologya (re-) view from Northern Europe. Heritage Sci. 1, 1-17. doi: 10.1186/20507445-1-15

Roeder, P. L., and Emslie, R. F. (1970). Olivine-liquid equilibrium. Contrib. Mineral. Petrol. 29, 275-289. doi: 10.1007/BF00371276

Santacroce, R., Cioni, R., Marianelli, P., Sbrana, A., Sulpizio, R., Zanchetta, G., et al. (2008). Age and whole rock-glass compositions of proximal pyroclastics from the major explosive eruptions of Somma-Vesuvius: a review as a tool for distal tephrostratigraphy. J. Volcanol. Geotherm. Res. 177, 1-18. doi: 10.1016/j.jvolgeores.2008.06.009

Saylor, B. Z., Poling, J. M., and Huff, W. D. (2005). Stratigraphic and chemical correlation of volcanic ash beds in the terminal Proterozoic Nama Group, Namibia. Geol. Magazine 142, 519-538. doi: 10.1017/S0016756805 000932

Schattel, N., Portnyagin, M., Golowin, R., Hoernle, K., and Bindeman, I. (2014). Contrasting conditions of rift and off-rift silicic magma origin on Iceland. Geophys. Res. Lett. 41, 5813-5820. doi: 10.1002/2014GL060780 
Schindlbeck, J., Freundt, A., and Kutterolf, S. (2014). Major changes in the postglacial evolution of magmatic compositions and pre-eruptive conditions of Llaima Volcano, Andean Southern Volcanic Zone, Chile. Bull. Volcanol. 76, 1-22. doi: $10.1007 / \mathrm{s} 00445-014-0830-\mathrm{x}$

Self, S., and Gertisser, R. (2015). Tying down eruption risk. Nat. Geosci. 8, 248-250. doi: $10.1038 /$ ngeo 2403

Shane, P. (2000). Tephrochronology: a New Zealand case study. Earth Sci. Rev. 49, 223-259. doi: 10.1016/S0012-8252(99)00058-6

Shane, P., and Hoverd, J. (2002). Distal record of multi-sourced tephra in Onepoto Basin, Auckland, New Zealand: implications for volcanic chronology, frequency and hazards. Bull. Volcanol. 64, 441-454. doi: 10.1007/s00445-0020217-2

Shane, P., Sikes, E. L., and Guilderson, T. P. (2006). Tephra beds in deep-sea cores off northern New Zealand: implications for the history of Taupo Volcanic Zone, Mayor Island and White Island volcanoes. J. Volcanol. Geotherm. Res. 154, 276-290. doi: 10.1016/j.jvolgeores.2006.03.021

Shane, P., and Wright, I. C. (2011). Late Quaternary tephra layers around Raoul and Macauley Islands, Kermadec Arc: implications for volcanic sources, explosive volcanism and tephrochronology. J. Quat. Sci. 26, 422-432. doi: $10.1002 /$ jqs. 1468

Siani, G., Sulpizio, R., Paterne, M., and Sbrana, A. (2004). Tephrostratigraphy study for the last $18,000{ }^{14} \mathrm{C}$ years in a deep-sea sediment sequence for the South Adriatic. Quat. Sci. Rev. 23, 2485-2500. doi: 10.1016/j.quascirev.2004.06.004

Siebert, L., Simkin, T., and Kimberly, P. (2010). Volcanoes of the World. Berkeley, CA; Los Angeles, CA: University of California Press.

Sigurdsson, H. (2000). "Volcanic episodes and rates of volcanism," in Encyclopedia of Volcanoes, eds H. Sigurdsson, B. Houghton, S. McNutt, H. Rymer, and J. Stix (San Diego, CA: Academic Press), 271-279.

Smith, V. C., Isaia, R., and Pearce, N. J. G. (2011a). Tephrostratigraphy and glass compositions of post-15 kyr Campi Flegrei eruptions: implications for eruption history and chronostratigraphic markers. Quat. Sci. Rev. 30, 3638-3660. doi: 10.1016/j.quascirev.2011.07.012

Smith, V. C., Mark, D. F., Staff, R. A., Blockley, S. P., Ramsey, C. B., Bryant, C. L., et al. (2011b). Toward establishing precise $40 \mathrm{Ar} / 39 \mathrm{Ar}$ chronologies for Late Pleistocene palaeoclimate archives: an example from the Lake Suigetsu (Japan) sedimentary record. Quat. Sci. Rev. 30, 2845-2850. doi: 10.1016/j.quascirev.2011.06.020

Smith, V. C., Pearce, N. J. G., Matthews, N. E., Westgate, J. A., Petraglia, M. D., Haslam, M., et al. (2011c). Geochemical fingerprinting of the widespread Toba tephra using biotite compositions. Quat. Int. 246, 97-104. doi: 10.1016/j.quaint.2011.05.012

Smith, V. C., Shane, P., and Nairn, I. A. (2005). Trends in rhyolite geochemistry, mineralogy, and magma storage during the last $50 \mathrm{kyr}$ at Okataina and Taupo volcanic centres, Taupo Volcanic Zone, New Zealand. J. Volcanol. Geotherm. Res. 148, 372-406. doi: 10.1016/j.jvolgeores.2005.05.005

Smith, V. C., Staff, R. A., Blockley, S. P. E., Bronk Ramsey, C., Nakagawa, T., Mark, D. F., et al. (2013). Identification and correlation of visible tephras in the Lake Suigetsu SG06 sedimentary archive, Japan: chronostratigraphic markers for synchronising of east Asian/west Pacific palaeoclimatic records across the last 150 ka. Quat. Sci. Rev. 67, 121-137. doi: 10.1016/j.quascirev.2013. 01.026

Stoffel, M., Khodri, M., Corona, C., Guillet, S., Poulain, V., Bekki, S., et al. (2015). Estimates of volcanic-induced cooling in the Northern Hemisphere over the past 1,500 years. Nat. Geosci. 8, 784-788. doi: 10.1038/ngeo2526

Straub, S. M. (2003). The evolution of the Izu Bonin-Mariana volcanic arcs (NW Pacific) in terms of major element chemistry. Geochem. Geophys. Geosys. 4, 1018. doi: $10.1029 / 2002 \mathrm{gc} 000357$

Straub, S. M., Goldstein, S. L., Class, C., Schmidt, A., and Gomez-Tuena, A. (2010). Slab and mantle controls on the $\mathrm{Sr}-\mathrm{Nd}-\mathrm{Pb}-\mathrm{Hf}$ isotope evolution of the post $42 \mathrm{Ma}$ Izu-bonin volcanic arc. J. Petrol. 51, 993-1026. doi: 10.1093/petrology/egq009

Straub, S. M., and Layne, G. D. (2003a). The systematics of chlorine, fluorine, and water in Izu arc front volcanic rocks: implications for volatile recycling in subduction zones. Geochim. Cosmochim. Acta 67, 4179-4203. doi: 10.1016/S0016-7037(03)00307-7

Straub, S. M., and Layne, G. D. (2003b). Decoupling of fluids and fluid-mobile elements during shallow subduction: evidence from halogen-rich andesite melt inclusions from the Izu arc volcanic front. Geochem. Geophys. Geosys. 4:7. doi: $10.1029 / 2002 \mathrm{gc} 000349$

Straub, S. M., Layne, G. D., Schmidt, A., and Langmuir, C. H. (2004). Volcanic glasses at the Izu arc volcanic front: new perspectives on fluid and sediment melt recycling in subduction zones. Geochem. Geophys. Geosys. 5:1. doi: $10.1029 / 2002 \mathrm{gc} 000408$

Straub, S. M., Woodhead, J. D., and Arculus, R. J. (2015). Temporal Evolution of the Mariana Arc: mantle Wedge and Subducted Slab Controls Revealed with a Tephra Perspective. J. Petrol. 56, 409-439. doi: 10.1093/petrology/ egv005

Sulpizio, R., Alçiçek, M. C., Zanchetta, G., and Solari, L. (2013). Recognition of the Minoan tephra in Acigöl Basin, Western Turkey: implications for inter archive correlations and fine ash dispersal. J. Quat. Sci. 28, 329-336, doi: $10.1002 /$ jqs. 2630

Sulpizio, R., Bonasia, L., Dellino, P., La Volpe, P., Mele, D., Zanchetta, G., et al. (2008). Discriminating the long distance dispersal of fine ash from sustained columns or near ground ash clouds: the example of the Avellino eruption (Somma-Vesuvius, Italy). J. Volcanol. Geotherm. Res. 177, 263-276. doi: 10.1016/j.jvolgeores.2007.11.012

Sulpizio, R., Van Welden, A., Caron, B., and Zanchetta, G. (2010b). The Holocene tephrostratigraphic record of Lake Shkodra (Albania and Montenegro). J. Quat. Sci. 25, 633-650. doi: 10.1002/jqs.1334

Sulpizio, R., Zanchetta, G., Caron, B., Dellino, P., Mele, D., Giaccio, B., et al. (2014). Volcanic ash hazard in the Central Mediterranean assessed from geological data. Bull. Volcanol. 76, 866. doi: 10.1007/s00445-014-0866-y

Sulpizio, R., Zanchetta, G., D’Orazio, M., Vogel, H., and Wagner, B. (2010a). Tephrostratigraphy and tephrochronology of lakes Ohrid and Prespa, Balkans. Biogeosciences 7, 3273-3288. doi: 10.5194/bg-7-3273-2010

Sun, C., Plunkett, G., Liu, J., Zhao, H., Sigl, M., McConnell, J. R., et al. (2014). Ash from Changbaishan Millennium eruption recorded in Greenland ice: implications for determining the eruption's timing and impact. Geophys. Res. Lett. 41, 694-701. doi: 10.1002/2013GL058642

Sun, C., You, H., He, H., Zhang, L., Gao, J., Guo, W., et al. (2015). New evidence for the presence of Changbaishan Millennium eruption ash in the Longgang volcanic field, Northeast China. Gondwana Res. 28, 52-60. doi: 10.1016/j.gr.2015.01.013

Sverrisdottir, G. (2007). Hybrid magma generation preceeding Plinian silicic eruptions at Hekla, Iceland: evidence from mineralogy and chemistry of two zoned deposits. Geol. Mag. 144, 643-659, doi: 10.1017/S0016756807003470

Swanson, D. A., Rose, T. R., Mucek, A. E., Garcia, M. O., Fiske, R. S., and Mastin, L. G. (2014). Cycles of explosive and effusive eruptions at Kîlauea Volcano, Hawai'i. Geology 42, 631-634. doi: 10.1130/G35701.1

Thorarinsson, S. (1950). The eruption of Mt. Hekla 1947 - 1948. Bull. Volcanol. 10 , 157-168. doi: 10.1007/BF02596085

Thordarson, T., Self, S., Oskarsson, N., and Hulsebosch, T. (1996). Sulfur, chlorine, and fluorine degassing and atmospheric loading by the 1783-1784 AD Laki (Skaftar Fires) eruption in Iceland. Bull. Volcanol. 58, 205-225. doi: $10.1007 / \mathrm{s} 004450050136$

Tomlinson, E., Thordarson, T., Müller, W., Thirlwall, M., and Menzies, M. (2010). Microanalysis of tephra by LA-ICP-MS-strategies, advantages and limitations assessed using the Thorsmörk Ignimbrite (Southern Iceland). Chem. Geol. 279, 73-89. doi: 10.1016/j.chemgeo.2010.09.013

Tomlinson, E. L., Arienzo, I., Civetta, L., Wulf, S., Smith, V. C., Hardiman, M., et al. (2012). Geochemistry of the Phlegraean Fields (Italy) proximal sources for major Mediterranean tephras: implications for the dispersal of Plinian and co-ignimbritic components of explosive eruptions. Geochim. Cosmochim. Acta 93, 102-128. doi: 10.1016/j.gca.2012.05.043

Tomlinson, E. L., Smith, V. C., Albert, P. G., Aydar, E., Civetta, L., Cioni, R., et al. (2015). The major and trace element glass compositions of the productive Mediterranean volcanic sources: tools for correlating distal tephra layers in and around Europe. Quat. Sci. Rev. 118, 48-66. doi: 10.1016/j.quascirev.2014.10.028

Turner, M. B., Cronin, S. J., Bebbington, M. S., Smith, I. E. M., and Stewart, R. B. (2011). Integrating records of explosive and effusive activity from proximal and distal sequences: Mt. Taranaki, New Zealand. Quat. Int. 246, 364-373. doi: 10.1016/j.quaint.2011.07.006

van den Bogaard, C., Jensen, B. J. L., Pearce, N. J. G., Froese, D. G., Portnyagin, M. V., Ponomareva, V. V., et al. (2014). Volcanic ash layers in Lake El'gygytgyn: 
eight new regionally significant chronostratigraphic markers for western Beringia. Clim. Past 10, 1041-1062. doi: 10.5194/cp-10-1041-2014

Voelker, A. H. L., and Haflidason, H. (2015). Refining the Icelandic tephrachronology of the last glacial period - the deep-sea core PS2644 record from the southern Greenland Sea. Global Planet. Change 131, 35-62. doi: 10.1016/j.gloplacha.2015.05.001

Wallace, P. J. (2001). Volcanic $\mathrm{SO}_{2}$ emissons and the abundance and distribution of exsolved gas in magma bodies. J. Volcanol. Geotherm. Res. 108, 85-106. doi: 10.1016/S0377-0273(00)00279-1

Wallace, P. J. (2005). Volatiles in subduction zone magmas: concentrations and fluxes based on melt inclusion and volcanic gas data. J. Volcanol. Geotherm. Res. 140, 217-240. doi: 10.1016/j.jvolgeores.2004.07.023

Watson, E. J., Swindles, G. T., Savov, I. P., and Bacon, K. L. (2015). First discovery of Holocene cryptotephra in Amazonia. Sci. Rep. 5:15579. doi: 10.1038/srep15579

Westgate, J., Pearce, N., Perkins, W., Preece, S., Chesner, C., and Muhammad, R. (2013). Tephrochronology of the Toba tuffs: four primary glass populations define the 75-ka Youngest Toba Tuff, northern Sumatra, Indonesia. J. Quat. Sci. 28, 772-776. doi: 10.1002/jqs.2672

Westgate, J. A., Froese, D. G., Pearce, N. J. G., and Perkins, W. T. (2011). A catalogue of late Cenozoic tephra beds in the Klondike goldfields and adjacent areas, Yukon Territory. Yukon Geological Survey Contribution 010. Can. J. Earth Sci. 48, 1386-1418. doi: 10.1139/ e10-110

Wiesner, M. G., Wetzel, A., Catane, S. G., Listanco, E. L., and Mirabueno, H. T. (2004). Grain size, areal thickness distribution and controls on sedimentation of the 1991 Mount Pinatubo tephra layer in the South China Sea. Bull. Volcanol 66, 226-242. doi: 10.1007/s00445-003-0306-x

WoldeGabriel, G., Hart, W. K., Katoh, S., Beyene, Y., and Suwa, G. (2005). Correlation of Plio-Pleistocene Tephra in Ethiopian and Kenyan rift basins: temporal calibration of geological features and hominid fossil records. J. Volcanol. Geotherm. Res. 147, 81-108. doi: 10.1016/j.jvolgeores.2005. 03.008

Wulf, S., Keller, J., Paterne, M., Mingram, J., Lauterbach, S., Opitz, S., et al. (2012). The 100-133 ka record of Italian explosive volcanism and revised tephrochronology of Lago Grande di Monticchio. Quat. Sci. Rev. 58, 104-123. doi: 10.1016/j.quascirev.2012.10.020
Wulf, S., Kraml, M., Brauer, A., Keller, J., and Negendank, J. F. W. (2004). Tephrochronology of the 100 ka lacustrine sediment record of Lago Grande di Monticchio (southern Italy). Quat. Int. 122, 7-30. doi: 10.1016/j.quaint.2004.01.028

Wulf, S., Kraml, M., and Keller, J. (2008). Towards a detailed distal tephrostratigraphy in the Central Mediterranean: the last 20,000 yrs record of Lago Grande di Monticchio. J. Volcanol. Geotherm. Res. 177, 118-132. doi: 10.1016/j.jvolgeores.2007.10.009

Wutke, K., Wulf, S., Tomlinson, E. L., Hardiman, M., Dulski, P., Luterbacher, J., et al. (2015). Geochemical properties and environmental impacts of seven Campanian tephra layers deposited between 40 and $38 \mathrm{ka}$ BP in the varved lake sediments of Lago Grande di Monticchio, southern Italy. Quat. Sci. Rev. 118, 67-83. doi: 10.1016/j.quascirev.2014.05.017

Zanchetta, G., Sulpizio, R., Roberts, N., Cioni, R., Eastwood, W. J., Siani, G., et al. (2011). Tephrostratigraphy, chronology and climatic events of the Mediterranean basin during the Holocene: an overview. Holocene 21, 33-52. doi: 10.1177/0959683610377531

Zdanowicz, C. M., Zielinski, G. A., and Germani, M. S. (1999). Mount Mazama eruption: calendrical age verified and atmospheric impact assessed. Geology 27, 621-624.

Zhao, H., and Hall, V. A. (2015). Assessing the potential for cryptotephra studies in Northeastern China. Holocene 25, 772-783. doi: 10.1177/0959683615569320

Zolitschka, B., Francus, P., Ojala, A. E. K., and Schimmelmann, A. (2015). Varves in lake sediments - a review. Quat. Sci. Rev. 117, 1-41. doi: 10.1016/j.quascirev.2015.03.019

Conflict of Interest Statement: The authors declare that the research was conducted in the absence of any commercial or financial relationships that could be construed as a potential conflict of interest.

Copyright $\odot 2015$ Ponomareva, Portnyagin and Davies. This is an open-access article distributed under the terms of the Creative Commons Attribution License (CC BY). The use, distribution or reproduction in other forums is permitted, provided the original author(s) or licensor are credited and that the original publication in this journal is cited, in accordance with accepted academic practice. No use, distribution or reproduction is permitted which does not comply with these terms. 